Felipe de Azevedo Lage Ferreira

\title{
An Empirical Risk Analysis of the Brazilian Shipbuilding Industry
}

\section{Dissertação de Mestrado (Opção profissional)}

Thesis presented to the Programa de PósGraduação em Engenharia de Produção of the Departamento de Engenharia Industrial, PUC-Rio, as partial fulfillment of the requirements for the degree of Mestre em Engenharia de Produção - opção profissional

Advisor: Prof. Luiz Felipe Roris Rodriguez Scavarda do Carmo Co-advisor: Profa ${ }^{a}$. Adriana Leiras 
Felipe de Azevedo Lage Ferreira

\section{An Empirical Risk Analysis of the Brazilian Shipbuilding Industry}

Thesis presented to the Programa de Pós-Graduação em Engenharia de Produção of the Departamento de Engenharia Industrial do Centro Técnico Cientifico da PUC-Rio, as partial fulfillment of the requirements for the degree of Mestre (professional option)

Prof. Luiz Felipe Roris Rodriguez Scavarda do Carmo Advisor Departamento de Engenharia Industrial - PUC-Rio Prof ${ }^{a}$. Adriana Leiras Co-advisor Departamento de Engenharia Industrial - PUC-Rio

Prof. Fabricio Carlos Pinheiro de Oliveira Departamento de Engenharia Industrial - PUC-Rio

Prof ${ }^{\mathrm{a}}$. Paula Santos Ceryno Departamento de Engenharia de Produção - UNIRIO

Prof. José Eugênio Leal Coordenador Setorial do Centro Técnico Científico - PUC-Rio 
All rights reserved.

Felipe de Azevedo Lage Ferreira

Graduated in Industrial Engineer at Pontificia Universidade Catolica do Rio de Janeiro - PUC-Rio in 2011. He worked for Ernst \& Young Terco as a Supply Chain advisor in 2011 and worked for Shipyard STX OSV in 2012. Since 2013 he works for Gearbulk.

Bibliographic data

Ferreira, Felipe de Azevedo Lage

An Empirical Risk Analysis of the Brazilian Shipbuilding Industry / Felipe de Azevedo Lage Ferreira ; advisor: Luiz Felipe Roris Rodriguez Scavarda do Carmo ; co-advisor: Adriana Leiras. - 2015.

81 f. : il. (color.) ; $30 \mathrm{~cm}$

Dissertação (mestrado)-Pontifícia Universidade Católica do Rio de Janeiro, Departamento de Engenharia Industrial, 2015.

Inclui bibliografia

1. Engenharia Industrial - Teses. 2. Engineer-toOrder. 3. Cadeia de Suprimento. 4. Gestão de Risco. 5. Brasil. I. Carmo, Luiz Felipe Roris Rodriguez Scavarda do. II. Leiras, Adriana. III. Pontifícia Universidade Católica do Rio de Janeiro. Departamento de Engenharia Industrial. IV. Título.

CDD: 658.5 


\section{Acknowledgments}

First of all, I want to thank my advisor Prof. Luiz Felipe Scavarda for believing in me to develop this work. I would like to express my gratitude to him and to my co-advisor Adriana Leiras for their ideas, commitment and valuable time to support me in this work. Without their guidance and persistent help this dissertation would not have been possible.

I acknowledge the professors who kindly accepted the invitations to collaborate with their experience for the evaluation of this study.

I am grateful to PUC's professors, staff and my colleagues who shared their time and knowledge with me.

Furthermore I would like to thank my fiancée Elisângela for her encouragement, support, advice, and understanding.

Last but not least, I am very grateful to my family, for all that they represent in my life. Especially to my mother and father who taught how valuable education is. 


\section{Abstract}

Ferreira, Felipe de Azevedo Lage; Carmo, Luiz Felipe Roris Rodriguez Scavarda. (Advisor) An Empirical Risk Analysis of the Brazilian Shipbuilding Industry. Rio de Janeiro, 2015. 81p. MSc. Dissertation (Opção profissional) - Departamento de Engenharia Industrial, Pontifícia Universidade Católica do Rio de Janeiro.

Supply Chain Management (SCM) is an area of growing interest by scholars and practitioners, and companies are increasingly paying attention to the role of risk in their business, in particular, to the development of Supply Chain Risk Management (SCRM) techniques. However, a gap in the literature is observed in regards to empirical studies on SCRM, in special for large projects as the shipbuilding industry, despite the fact that many characteristics of this industry - such as long lead times, complex processes, financial intensity and dynamic organization structures - make it fundamentally vulnerable to risks. For the Brazilian shipbuilding in particular, empirical evidence also showed to be more crucial, not only because there is a scarcity of studies for shipbuilding in general, but also because the Brazilian shipbuilding industry experienced a long period of stagnation during the 80 s and 90 s decades. This study attempts to fulfill this gap, by identifying the main supply chain risks for Brazilian ship builders and offering an initial risk profile for the industry. The study integrated and implemented methodologies proposed by other scholars in the field to develop a survey approach targeted at experts from shipyards in Brazil. The survey asked participants to: (1) identify the main risks present in the Brazilian shipbuilding industry; (2) evaluate the likelihood of their occurrence; and (3) recognize main sources and potential impacts, as well as potential strategies to mitigate them. The study confirmed the presence of risks identified in the literature and new ones of particular importance to the Brazilian context. The study also yielded a preliminary risk profile for the Brazilian shipbuilding industry.

\section{Keywords}

Engineer-to-Order; Supply Chain; Risk Management; Brazil. 


\section{Resumo}

Ferreira, Felipe de Azevedo Lage; Carmo, Luiz Felipe Roris Rodriguez Scavarda. Análise Empírica de Risco da Indústria Naval Brasileira. Rio de Janeiro, 2015. 81p. Dissertação de Mestrado - Departamento de Engenharia Industrial, Pontifícia Universidade Católica do Rio de Janeiro.

A Gestão da Cadeia de Suprimento é uma área de crescente interesse na literatura, e da mesma forma as companhias estão cada vez mais voltando à atenção, especificamente, para técnicas para Gestão de Risco da Cadeia de Suprimento. Porém, existe uma carência na literatura para estudos empíricos da Gestao de Risco, em particular para grandes projetos como a construção naval, mesmo sendo muitos das características dessa indústria - como longos períodos de lead time, complexos processos produtivos, alto investimento de capital e estruturas de organização dinâmica - aumenta a sua exposição a riscos. Existe um gap na literatura com relação à gestão de risco para estudos empíricos, em especial para grandes projetos, como a construção naval. No Brasil em específico, esta carência da indústria se tornou mais evidente devido ao fato da indústria de construção naval no Brasil ter vivenciado um longo período de recessão nas décadas de 80 e 90. Este estudo empírico visa preencher essa lacuna, através da identificação dos principais riscos da cadeia de suprimentos para os principais estaleiros brasileiros e oferecendo um perfil de risco inicial para que a indústria. Foi realizada uma coleta de dados com os estaleiros visando (1) identificar os principais riscos presentes na indústria naval brasileira; (2) avaliar a probabilidade de ocorrência destes riscos; e (3) reconhecer as fontes principais e potenciais impactos de riscos, bem como possíveis estratégias para mitigar os riscos. O estudo confirmou a presença de riscos identificados em estudos da indústria de construção naval em outros países, e também identificou novos riscos relevantes no contexto brasileiro. Por fim, for apresentado um perfil de risco para a indústria naval brasileira.

\section{Palavras-chave}

Engineer-to-Order; Cadeia de Suprimento; Gestão de Risco; Brasil. 


\section{Contents}

$\begin{array}{lr}\text { 1. Introduction } & 11\end{array}$

2. Conceptual Foundation 14

2.1. Supply Chain Management (SCM) 14

2.2. Supply Chain Structures $\quad 15$

$\begin{array}{lr}\text { 2.3. Engineer-to-order } & 17\end{array}$

3. Literature Review 21

3.1. Risk and SC Risk Sources $\quad 21$

3.2. Supply Chain Risk Management (SCRM) 25

$\begin{array}{ll}\text { 3.3. Shipbuilding risks } & 29\end{array}$

4. Shipbuilding overview 34

4.1. Shipbuilding industry 34

4.2. Shipbuilding main actors 36

4.3. Shipbuilding macro processes 39

4.4. Shipbuilding activity costs 41

4.5. Shipbuilding global market overlook 42

5. Research design and methodology 45

6. Results and discussion 52

$\begin{array}{ll}\text { 7. Conclusion and future research } & 61\end{array}$

$\begin{array}{lr}\text { References } & 64\end{array}$

$\begin{array}{ll}\text { Appendix I - Survey Rounds } 1 \text { and } 2 & 77\end{array}$

Appendix II - Survey Round $3 \quad 81$ 


\section{List of figures}

Figure 1 - Types of CODP 16

$\begin{array}{lr}\text { Figure } 2 \text { - ETO overlapping processes } & 19\end{array}$

Figure 3 - Internal or External Risk Sources 25

Figure 4 - SCRM Process $\quad 26$

$\begin{array}{ll}\text { Figure } 5 \text { - Shipbuilding risks types } & 31\end{array}$

Figure 6 - Shipbuilding industry links 34

Figure 7 - Shipbuilding macro Supply Chain 36

Figure 8 - Shipbuilding processes overview 39

Figure 9 - Shipbuilding macro expenses $\quad 42$

Figure 10 - World's new ship orders $\quad 44$

Figure 11 - Methodology summary 45

Figure 12 - Risk map/matrix groups and actions remove 50

Figure 13 - Methodology expanded overview 51

Figure 14 - Brazilian shipbuilding risk profile $\quad 55$

Figure 15 - Brazilian shipbuilding workforce 58 


\section{List of tables}

Table 1 - Literature definitions and characteristics for ETO 18

Table 2 - Taxonomy for ETO companies $\quad 20$

Table 3 - Supply Chain risks 22

Table 4 - World's new ship orders book 43

Table 5 - Main risks in Brazilian shipbuilding industry 53

Table 6 - Risk assessment result

Table 7 - Risk exposure levels 56

Table 8 - Risk ranking by risk category $\quad 57$ 


\section{List of acronyms}

AHP - Analytic Hierarchy Process

ARF - Analytical Risk Framework

ATO - Assemble-to-Order

BTO - Build-to-Order

CPFR - Collaborative Planning, Forecasting, and Replenishment

CODP - Customer Order Decoupling Point

DWT - Deadweight tonnage

ERP - Enterprise Resource Planning

ETA - Event Tree Analysis

ETO - Engineer-to-Order

FMEA - Failure Mode and Effect Analysis

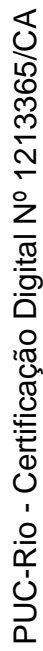

FTA - Failure Tree Analysis

KPI - Key Process Indicator

MAD - Median Absolute Deviation

MTO - Make-to-Order

MTS - Make-to-Stock

OPP - Order Penetration Point

SC - Supply Chain

SCM - Supply Chain Management

SCRM - Supply Chain Risk Management

SD - Standard Deviation

VAR - Value at Risk

VFPE - Value Focused Process Engineering

VMI - Vendor Managed Inventor 


\section{1. \\ Introduction}

In today's globalized and highly competitive environment, Supply Chains (SC) became larger and more complex with globally dispersed components (Blackhurst et al., 2005; Chapman, 2006). The more complex the SC is, less predictable is the likelihood and the impact of disruption, which indicate a higher exposition to SC risks (McGillivray, 2000; Engardio, 2001; Harland et al., 2003; Christopher and Lee, 2004; Finch, 2004; Jüttner, 2005; Kleindorfer and Saad, 2005; Tummala and Schoenherr, 2011).

Recently, companies have given more attention to disruption or contingency plans by developing a Supply Chain Risk Management (SCRM) technique, in order to avoid the identified SC risks, or if not possible, to mitigate or control them. For that reason, it is necessary that firms understand SC interdependencies and be able to identify potential risk factors by measuring their likelihood and consequences. (Norrman and Jansson, 2004; Hendricks and Singhal, 2005; Pujawan and Geraldin, 2009; Thun and Hoenig, 2009; Tang and Musa, 2011; Tazelaar and Snijders, 2011; Tummala and Schoenherr, 2011; Ceryno et al., 2014).

According to Jüttner (2005), SCRM is still a recent subject and a very specific task to many industries. For Tang (2006) only minorities of companies have implemented adequate methods for SCRM, although they are quite aware of the consequences of SC risks.

Recent studies by Tang and Musa (2011) and Sodhi et al. (2012), claim that there are three gaps in SCRM: (1) there is no clear definition of SCRM, (2) lack of research on mitigating supply chain risk and (3) clear deficiency of empirical studies in this area.

The lack of empirical research is even more critical for large projects as for ship construction ( $\mathrm{Lu}$ and Tang 2000, Moyst and Das, 2005). Additionally, when compared to many other industries, shipbuilding, as a typical Engineer-to-order production (ETO), is more exposed to SC risks due to the unique features of this 
activity, such as long lead time, complex processes, financial intensity and dynamic organization structures (Kanerva, 2004; Moyst and Das, 2005; Lee et al., 2009; Basuki et al., 2010). The uncertainties within an ETO production are basically from the product specification and design, and demand forecast for the manufacturing process. These uncertainties have great influence on the complexity of the production control situation and serious impact on lead-time duration (Galbraith, 1973). Hence, taking effective SCRM techniques to manage these variables of ship construction along the SC is important to a successful delivery of a ship project (Flanagan and Norman, 1993; Akintoye and MacLeod, 1996).

For the Brazilian shipbuilding in particular, empirical evidence also showed to be crucial, not only because there is a scarcity of studies for shipbuilding in general, but also because the Brazilian shipbuilding industry experienced a long period of stagnation, reducing to almost zero the investments and researches in the area (Lima, 2009). Only in recent years it started again to receive attention of academics and practitioners, due to the boom generated by the deep-water oil exploration in Brazil (Lima, 2009; Faverin et al., 2010 a; Queiroz, 2012). During this strong period of growth, Brazilian shipyards are still dealing with great challenges in their development, which has not yet reached a level of global competitiveness (Coutinho, 2006; Faverin et al., 2010 a; Queiroz, 2012).

The uncertainties presented in this industry allow a great opportunity for research and development for SCRM techniques. Hence, this study purposes to identify the main risks along the shipbuilding supply chain by probability and severity of occurrence. In addition, it is proposed the construction of an initial risk profile for the Brazilian shipbuilding, in order to obtain a better outline of this industry. Furthermore, this approach contributes to fulfill a gap in the literature for empirical researches in SCRM and also can help professionals to better understand the vulnerabilities related to ship construction around the risk concept. Moreover, the identification of risks can also be viewed as the trigger for SCRM and could serve as a guide for practitioners to start the SCRM processes (Kern et al., 2012; Ceryno et al., 2014). The SCRM process helps to access, analyze and treat areas of vulnerability and risk in supply chains (Nieger et al., 2009; Ceryno 
et al., 2014). The research goal is achieved based on a survey approach with three Round of questionnaires. The survey included executives from major shipbuilders considering their steel processing capacity.

The dissertation is organized into 7 chapters, beginning with this introduction. Chapter 2 provides a conceptual foundation around SCM and SCM structures, focusing on ETO production. Next, Chapter 3 outlooks the literature review for risk and SCRM concept and techniques, followed by Chapter 4 that presents the main characteristics for the shipbuilding activity and also a global market overview for this industry. Chapter 5 that presents the research method. Finally, Chapters 6 and 7 bring the research results and discussion, and propose a future research for this study. 


\section{2. \\ Conceptual Foundation}

This chapter presents the main definitions and concepts about SCM and SC structures, with special attention to ETO, as a typical shipbuilding structure.

\section{1. \\ Supply Chain Management (SCM)}

Over the past two decades, SCM has come to be seen as a key component of organizational competitiveness and effectiveness. In this way, the interest in the concept of SCM increased significantly when companies saw the benefits of collaborative relationships within and beyond their own organization. Moreover, continuous advances in communication and transportation technologies have motivated the evolution of supply chain and to effective managing techniques, such as Enterprise Resource Planning (ERP) systems, Vendor Managed Inventor (VMI), Collaborative Planning, Forecasting, and Replenishment (CPFR), and others (Porter, 1985; Mentzer et al., 2001; Khan and Burnes, 2007; Simchi-Levi et al., 2008).

While interest in SCM is immense, it is clear that much of the knowledge about the theme resides in narrow functional fields such as purchasing, logistics, IT and marketing. By virtue of this, a number of definitions have been proposed concerning the concept of "the supply chain" and its management (Burgess et al., 2006).

Scott and Westbrook (1991) and New and Payne (1995) describe supply chain management as the chain linking each element of the manufacturing and supply process from raw materials through to the end user.

Lambert and Cooper (2000) state a similar definition for SCM as, "the integration of key business processes from end-user through original suppliers that provides products, services, and information that add value for customers and other stakeholders". Simchi-Levi et al. (2008) define SCM as a series of activities concerning the planning, coordinating and controlling movement of materials, parts, and products from the suppliers to the customer. This includes the management of material, information and financial flows in the supply chain. 
However, as Hendricks and Singhal (2005) argue, by developing SCM, which focus on cost reduction and effectiveness, the organizations have ignored or played down the risks from a disruption to the entire supply chain. In this way, companies became more aware that they can no longer effectively compete in isolation of their suppliers and other entities. Modern SC are in fact dynamics networks of interconnected firms and industries (Lummus and Vokurka, 1999; Mentzer et al., 2001).

Many researchers have sought to investigate the relationship between risk and supply chain management. This is considered as initial step when understanding the SC risks and a further SCRM method (Kraljic, 1983; Puto et al., 1985; Eisenhardt, 1989; Pilling and Zhang, 1992; Ragatz et al., 1997; Hallikas et al., 2000; Zsidisin et al., 2000; Macintosh, 2002; Harland et al., 2003; Karjalainen et al., 2003).

\section{2. \\ Supply Chain Structures}

As well as understanding the SCM and its SC risks, it is also important to observe the characteristics and particularities of production systems, in order to understand the features and uncertainties and also the relationship between productive activities (Lustosa et al., 2008), in particular for shipbuilding production system, as center of this study.

Based on Rudberg and Wikner (2004) and Olhager (2010), there are four basic types of production systems: Engineer-to-Order (ETO), Make-to-Order (MTO), Assemble-to-Order (ATO), and Make-to-Stock (MTS), often referred as 'supply chain structures'.

In terms of the lead time and product customization, these supply chain structures can be organized around the concept of customer order decoupling point (CODP) (Gosling and Naim, 2009). CODP is most often defined as the point in the material flow where the product is tied to a specific order from the client. In the literature, this point has received different denominations. Some authors define it only as decoupling point (DP), others as order penetration point (OPP) (Yang and Burns 2003; Olhager 2003; Olhager 2010). 
Sharman (1984) also introduces CODP in a logistics context, emphasizing the product specifications and stock. He defines CODP as the point where specifications are typically unchanged until demand is known, and the last point at which the stock is held.

In other words, CODP divides the production cycle in two distinct stages as shown in Figure 1: prior to decoupling point the product value chain remains based on forecast activities; whereas after decoupling point it's driven by the market demand (Rudberg and Wikner, 2004). Thus, all activities in supply chain performed after the CODP are customized and targeted at the specific customer order, while all activities in the supply chain performed before the CODP are standardized (Yang and Burns, 2004).

Additionally, due to the possible market uncertainties, CODP may act as a strategic buffer between fluctuating customer order and/or product variety. Volatile markets require agility in decision making and quick reactions in order to ensure that customer needs are met in the shortest time and at the lowest cost (Bertrand and Muntslag, 1993; Naylor et al., 1999).

Figure 1 - Types of CODP

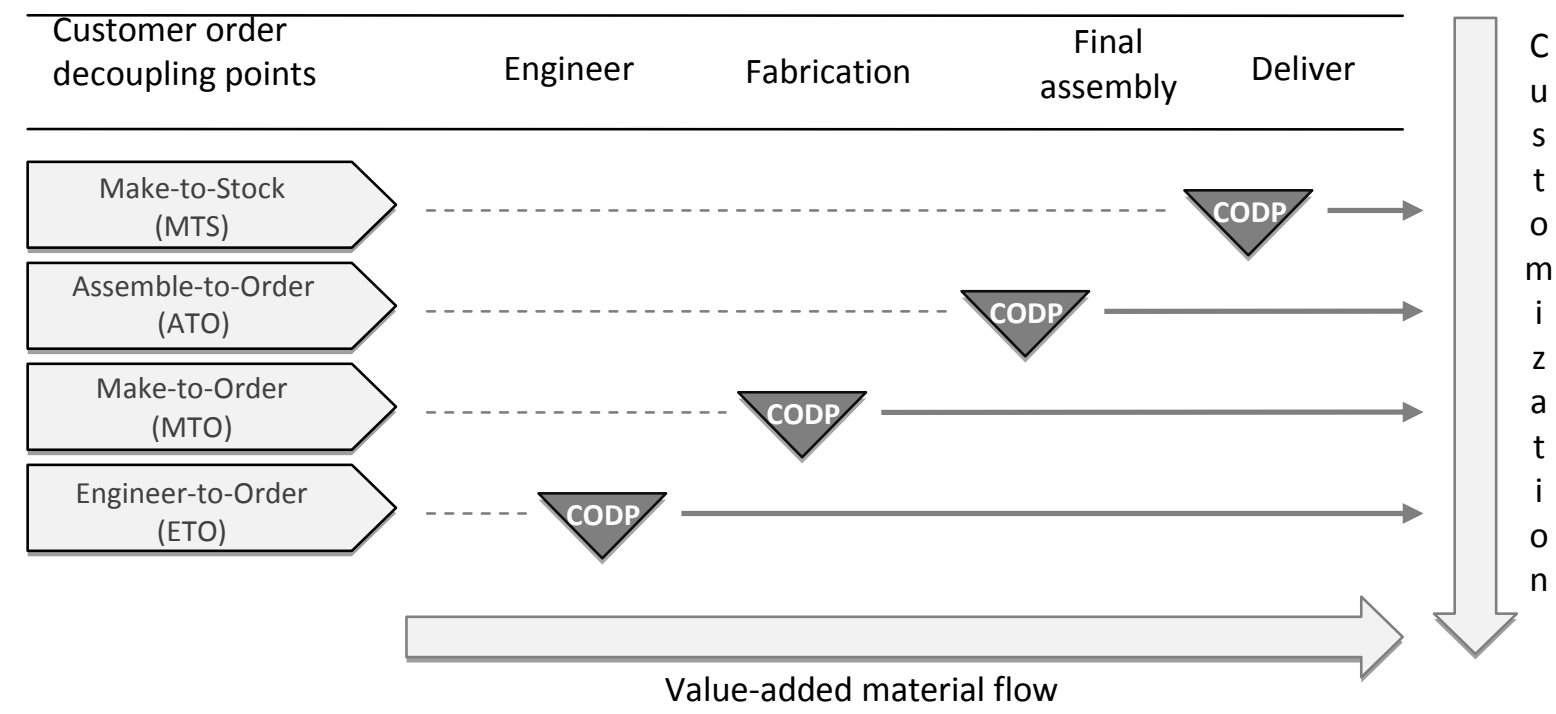

Source: Based on Olhager, 2003; Rudberg and Wikner, 2004 
Hoesktra and Romme (1992), Porter et al. (1999), Amaro et al. (1999), and Olhager (2003) explored the ways of classifying these logistics structures in conjunction with distinct decoupling point settings, as follows:

- Make-to-Stock (MTS) - Standardized products are produced based on demand forecasts and any customized product is manufactured. This structure has the advantage of quick delivery items, but generates high levels of stock, which is vulnerable to forecast demands more accurately. In MTS the decoupling point is located at finished goods;

- Assemble-to-Order (ATO) - This structure means in principle that all materials are sourced and all component manufacturing is carried out without connection to specific customer orders. In this case the decoupling point is located at sub-assemblies within the assembly process.

- Make-to-Order (MTO) - The final product is developed from contacts with the customer and delivery times are usually long. The decoupling point is located at purchased goods;

- Engineer-to-Order (ETO) - This structure is an extension of MTO strategy, since the design and engineering of the product is also custom made (Rocha et al., 2005). But for this production system, the decoupling point is located at the design stage, so each customer order penetrates at the design phase of a product.

Shipbuilding, as focus of this study, is a typical ETO industry. This type of supply chain structure basically starts upon a project sale, which is the point marked by the CODP. At this stage the contract is signed and the detailed design and production begin (Walter and Ries, 1996; Gosling and Naim, 2009).

\section{3.}

\section{Engineer-to-order}

In the literature, different terms are often used to describe very similar operation systems as ETO, such as one-of-a-kind (Hameri, 1997) and design-toorder (Hicks et al., 2000). For that reason, this study searched for main definitions around the ETO concept in order to build a clear description for this production system. 
Table 1 - Literature definitions and characteristics for ETO

\begin{tabular}{lcc}
\hline \multicolumn{1}{c}{ Definition } & Authors \\
\hline $\begin{array}{l}\text { Customized production dimensions with the } \\
\text { decoupling point located at the design stage }\end{array}$ & 1996; Rudberg and Wikner, 2004 \\
\end{tabular}

The ETO supply chain is usually associated as large and complex project environments

Gosling and Naim, 2009

ETO supply chains offer customized products where

Amaro et al., 1999; Rudberg and completely new designs are developed to order

Wikner, 2004;

ETO is a type of manufacturing process for highly customized products which are required to be designed

Cho and Porter, 1986; Pandit and Y. and engineered in detail as customer's orders Zhu, 2007; Clark et al., 2007 specification

Companies making ETO products are essentially project (value stream) driven and are typically Cameron and Braiden, 2004. involved in several concurrent projects at any one time.

ETO companies are characterized by time-limited projects related to the supply of complex equipment to third parties, and this process often includes the Caron and Fiore, 1995 phases: design, manufacturing, installation, and commissioning

Offers a standard product range with the availability of modifications and customizations

Galbraith, 1973; Porter el al., 1999

Based on the findings observed in the literature in Table 1, ETO can be associated to low-volumes, high degrees of customization, long lead times and project-based process, which are in contrast to high-volume manufacturing. Also, ETO has a typical large and complex project environments, where often includes the phases of design, manufacturing, and commissioning.

According to Galbraith (1973) an ETO production is characterized as project based and very customized, these main factors have a great influence on 
the complexity of the production control and serious impact on lead-time duration. Walter and Ries, (1996) and Hicks et al. (2000) states that in ETO industry, it is common for key procurement and manufacturing activities to be associated with long lead-time, where these activities take place before the design is finished. As a result, production planning is constantly under changes during construction phases causing delays and rework, as well with wrong purchases.

In order to minimize impacts of long lead times, it is usual to have overlaps between the different stages of the production process: engineering, planning, procurement and production, as shown in Figure 2. Not only the processes can often overlap but also the order and amount of effort put into each process can vary (Walter and Ries, 1996).

Figure 2 - ETO overlapping processes

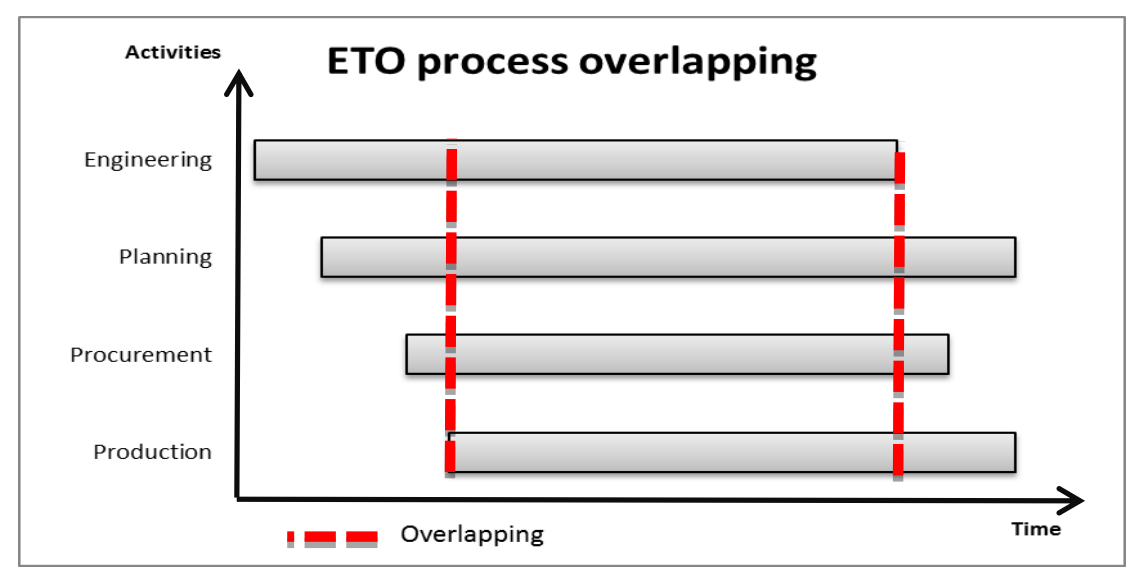

Source: Based on Walter and Ries (1996)

Additionally, the literature offers different classifications for ETO companies. For instance, Amaro et al. (1999) suggest four types of ETO, which is constructed on the basis of three major dimensions. The first is the degree of product customization, covering pure customization, tailored customization and standard customization. Amaro et al. (1999) ETO types were all are characterized as pure customized products as first dimension, and by their responsibility to the design and specification of products, the sourcing and purchasing of materials relative to the customer, as second dimension. Finally, the activities performed by 
the company as assembly, processing (or fabrication), purchasing, specification and design correspond to the third dimension. These three dimensions compose the four types of ETO as demonstrated in Table 2.

Table 2 - Taxonomy for ETO companies

\begin{tabular}{lcccc}
\hline \multicolumn{1}{c}{ Classification } & ETO 1 & ETO 2 & ETO 3 & ETO 4 \\
\hline Degree of customization: & & & & \\
Pure & $\sqrt{ }$ & $\sqrt{ }$ & $\sqrt{ }$ & $\sqrt{ }$ \\
Tailored & - & - & - & - \\
Standardized & - & - & - & - \\
None & - & - & - & - \\
\hline Company responsibility for: & & & & \\
Design & $\sqrt{ }$ & - & - & - \\
Specification & $\sqrt{ }$ & $\sqrt{ }$ & - & - \\
Purchasing & $\sqrt{ }$ & $\sqrt{ }$ & - \\
\hline Activities after receipt of order: & & & & \\
Delivery & $\sqrt{ }$ & $\sqrt{ }$ & $\sqrt{ }$ & $\sqrt{ }$ \\
Assembly & $\sqrt{ }$ & $\sqrt{ }$ & $\sqrt{ }$ & $\sqrt{ }$ \\
Processing & $\sqrt{ }$ & $\sqrt{ }$ & $\sqrt{ }$ & - \\
Purchasing & $\sqrt{ }$ & $\sqrt{ }$ & - & - \\
Specification & $\sqrt{ }$ & $\sqrt{ }$ & - & - \\
Design & $\sqrt{ }$ & - & & \\
\hline
\end{tabular}

Source: Based on Amaro et. Al (1999)

Hicks et al. (2001) also develop a typology of four ETO companies, in order to explain how production processes are organized and examine the impact of market changes on the configuration of production processes. His framework has shown that ETO companies can be classified according to the level of vertical integration, product complexity and the volume of production.

Hicks et al. (2000) conclude that the project concept and basic and functional design are the non-physical processes, and considered as the core capabilities for ETO companies. 


\section{3. \\ Literature Review}

This chapter offers a brief overview of the literature of SCRM regarding key definitions for risks and SC risks, as for shipbuilding risks. This chapter also describes the SCRM process and main techniques used in the literature.

\section{1.}

\section{Risk and SC Risk Sources}

The term 'risk' is normally associated with uncertainty (Zsidisin, 2003; Jüttner et al., 2003; Khan and Burnes, 2007). Knight (1921) made a simple distinction between risk and uncertainty, defining risk as something measurable and manageable that can be made of the probabilities of the outcomes, while uncertainty is not quantifiable and the probabilities of the possible outcomes are not known. According to Manuj and Mentzer (2008), risk can be defined as the combination of probability of occurrence and the severity of an unwanted event. However, Yates and Stone (1992) argue that every conception of risk implies that there must be uncertainty about the prospective outcomes, and if the probability of those outcomes is known, there is no risk. This research does intend to contribute on the definition around risk and uncertainties, adopting the concept that risk is both measurable and manageable.

Depending on the field of research, the term risk is expressed with a variety of meanings, measurements, and interpretations (Wagner and Bode, 2006). At an academic level, a growing body of research on risk has emerged from a number of different fields, such as accounting, finance, economics, marketing, business, supply chain (Zsidisin, 2003, Jüttner, 2005; Wagner and Bode, 2006). Regardless of the area of interest, risk is always associated with an undesirable loss created by an unwanted negative consequence and uncertainty. This study focused on SC risks.

According to Christopher et al., (2004) Supply Chain risk has been defined as "any risk to the information, material and product flow from original suppliers to the delivery of the final product". 
Goh et al. (2007) classify SC risks based on their sources, differentiating risks arising from the internal of the SC network from those created by the external environments. In a similar definition, Kleindorfer and Saad (2005) categorized SC risks into operations and disruptions risks. According to Tang (2006), the operations risks are associated with uncertainties inherent in a SC, which include demand, supply, and cost uncertainties. Quinn (2006) refers to disruption risks caused by major natural and man-made disasters such as flood, earthquake, tsunami, and major economic crisis. Both operations and disruption risks could seriously disrupt and delay materials, information, and cash flow, which in the end could damage sales, increase costs, or both (Chopra and Sodhi, 2004).

Zsidisin (2003), Christopher and Peck (2004), Manuj and Mentzer (2008), suggest four categories of risk as supply, demand, operational, and security. Similarly, Christopher and Lee (2004) identify process, control, demand, supply, and environment as risk sources, while Chopra and Sodhi (2004) present nine risk sources as disruptions, delays, systems, forecast, intellectual property, procurement, receivables, inventory and capacity. Table 3 presents an illustrative list of supply chain sources, compiled from the various studies in the literature.

Table 3 - Supply Chain risks

\begin{tabular}{|c|c|c|}
\hline Risk Category & Risk Source & Reference \\
\hline Demand & $\begin{array}{l}\text { - } \text { Order fulfillment errors } \\
\text { - Inaccurate forecasts }\end{array}$ & $\begin{array}{l}\text { Chopra and Sodhi (2004); } \\
\text { Christopher and Peck (2004); } \\
\text { Quinn, (2006); Tummala and } \\
\text { Schoenherr (2011) }\end{array}$ \\
\hline Delay & $\begin{array}{l}\text { - High capacity utilization at } \\
\text { - Inflexibility of supply } \\
\text { - } \text { source } \\
\text { - Transportation breakdowns } \\
\text { - Excessive Handling } \\
\text { - Custom clearances }\end{array}$ & $\begin{array}{l}\text { Chopra and Sodhi (2004); } \\
\text { Christopher and Lee (2004); } \\
\text { Kleindorfer and Saad, (2005) }\end{array}$ \\
\hline
\end{tabular}




\begin{tabular}{|c|c|c|}
\hline Disruption & $\begin{array}{ll}\text { - } & \text { Natural disaster } \\
\text { - } & \text { Labor dispute/strike } \\
\text { - } & \text { Supplier bankruptcy } \\
\text { - } & \text { War and terrorism }\end{array}$ & $\begin{array}{l}\text { Chopra and Sodhi, (2004); } \\
\text { Christopher and Lee (2004); } \\
\text { Christopher and Peck (2004) }\end{array}$ \\
\hline Inventory & $\begin{array}{l}\text { - } \text { Rate of product } \\
\text { obsolescence } \\
\text { - Inventory holding cost } \\
\text { - Demand and supply } \\
\text { uncertainly }\end{array}$ & $\begin{array}{l}\text { Chopra and Sodhi (2004); } \\
\text { Christopher and Lee, 2004; } \\
\text { Schoenherr et al., } 2008\end{array}$ \\
\hline
\end{tabular}

- Exchange rate risk

- Percentage of a key component or raw material procured from a single Chopra and Sodhi, 2004; Christopher and Lee, 2004;

Procurement source

- Industry wide capacity Christopher and Peck, 2004; utilization Schoenherr et al., 2008

- Long-term versus shortterm contracts

- Exceeding budget and schedule plan

Project

- Project design versus Jüttner, 2005; Lee et al., 2009 manufacturing capability

- Product specification

- Product standardization maintaining quality

Zsidisin, 2003; Christopher and Peck, 2004

- Vertical integration of supply chain Christopher and Peck, 2004;

Intellectual Property

- Global outsourcing and Manuj and Mentzer 2008 markets

- Regional instability

Sovereign

- Communication difficulties

Christopher and Peck, 2004;

- Government regulation 


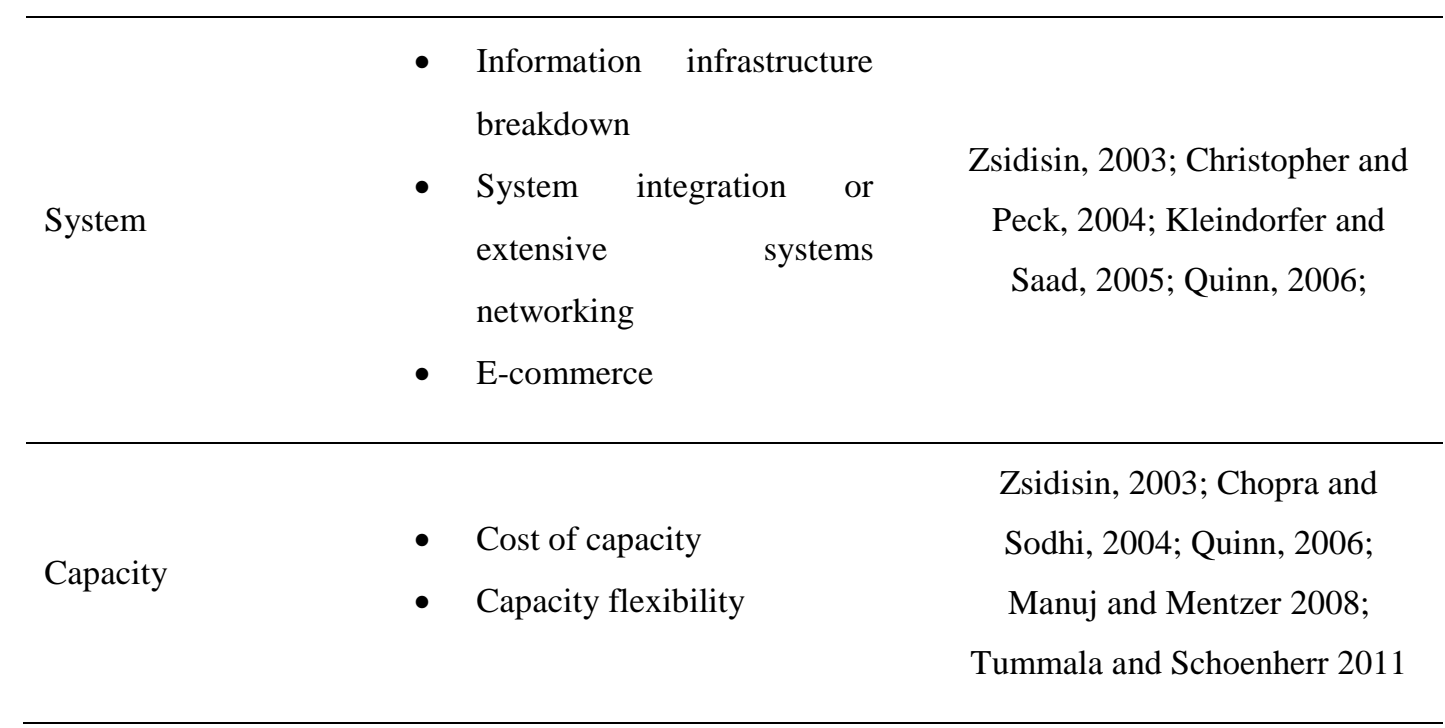

As Goh et al. (2007) and Gilaninia et al. (2013) presented, risk sources can be also extended to a view of internal or external risks. According to Kleindorfer and Saad (2005), external supply chain holds environmental factors altering from political reasons, economic, technological or geographical. In the other hand, internal supply chain risk, as defined by Rice and Caniato (2003) is caused by problems in organizational boundaries and internal SC network including machinery or equipment failure, system breakdown, inventory issues and others. Following this criteria, risk sources can be divided into internal or external influences as below Figure 3 . 
Figure 3 - Internal or External Risk Sources

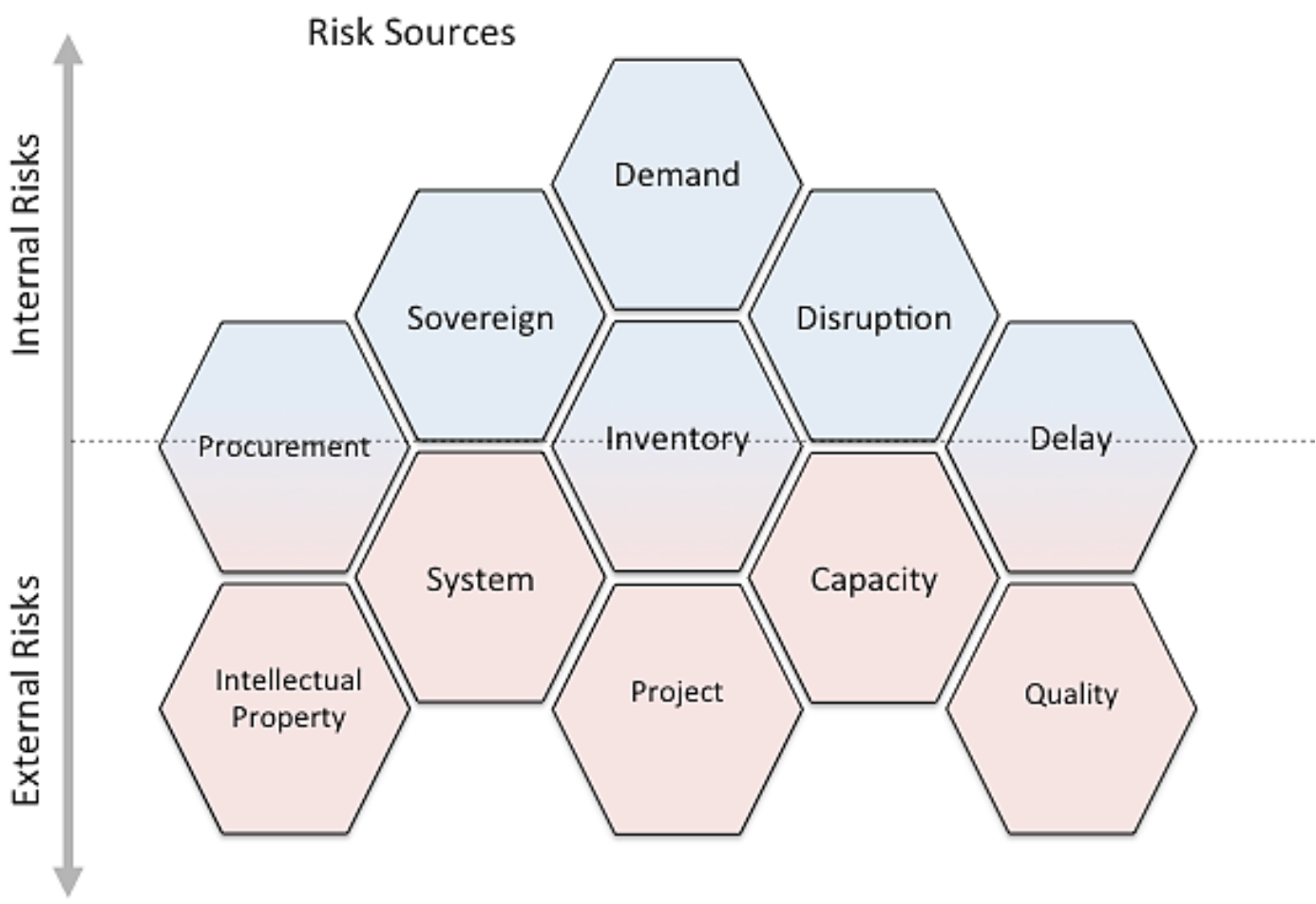

Source: Based on Goh et al. (2007); Gilaninia et al. (2013)

\section{2. \\ Supply Chain Risk Management (SCRM)}

Risk management is in general described as the identification and analysis of risks, as well as their monitoring and mitigation (Ceryno et al., 2014). A main particularity of SCRM, contrary to traditional risk management, is that it is characterized by a cross-company orientation aiming at the identification and reduction of risks not only on the company level, but rather focusing on entire supply chains (Jüttner, 2005)

To survive in a risky business environment, it is imperative for companies to have a proper SCRM. If poorly handled, disruptions in SC could result in costly delays causing deficient service level and high costs (Hendricks and Singhal, 2003; Blackhurst et al., 2005). As stated by Norrman and Jansson (2004) and 
Jüttner (2005), the focus of SCRM is to understand, and try to avoid, the devastating effects that disasters or even minor business disruptions can have in a SC.

In the literature, the SCRM process is described in similar ways, which can vary from risk identification and/or measurement, risk assessment and/or risk evaluation to mitigation plans and control and/or monitoring (Hallikas et al., 2002; Neiger et al., 2003; Jüttner et al. 2005; Kleindorfer and Saad 2005; Tse et al., 2005; Cucchiella and Gastaldi, 2006; Ritchie and Brindley, 2007; Adhitya et al., 2008; Knemeyer et al., 2009; Giannakis and Louis, 2011; Tummala and Schoenherr, 2011; Kern et al., 2012; Ghadge et al., 2013; Ceryno et al., 2014; Elleuch et al., 2014). Different systems have been put forward but most approaches for SCRM process tend to follow the generic process shown in Figure 4.

Figure 4 - SCRM Process

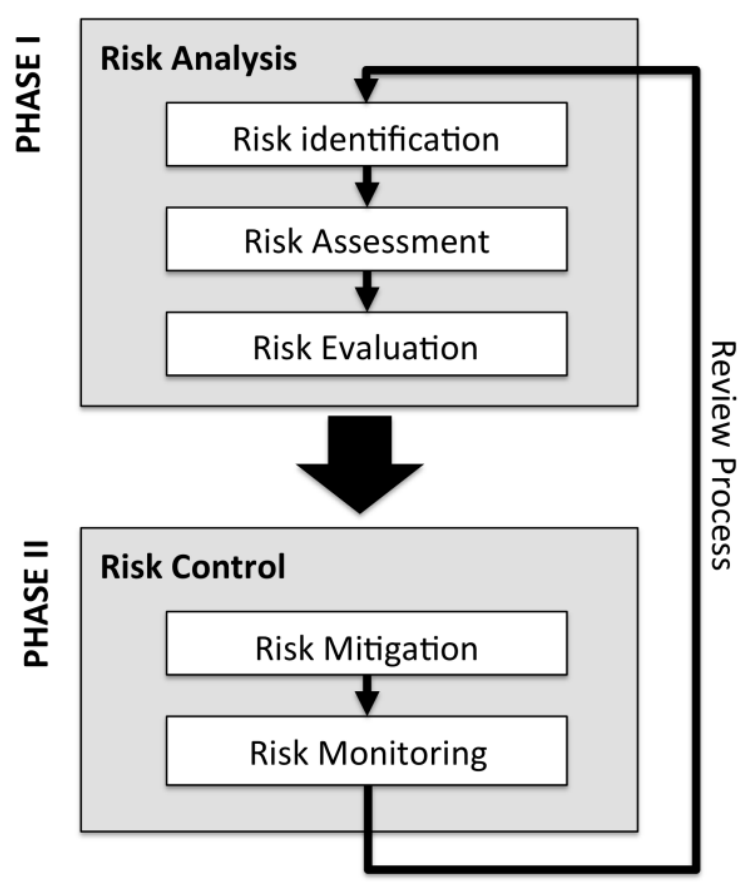

Based on White (1995); Neiger et al. (2003); Jüttner et al. (2005); Kleindorfer and Saad (2005); Knemeyer et al. (2009); Tse et al. (2005); Tummala and Schoenherr (2011). 
As seen in Figure 4, the literature essentially presents two main phases for SCRM: Phase I, which corresponds the risk analysis from Risk Identification, Risk Assessment, and Risk Evaluation; and Phase II, which involves risk control from Risk Mitigation and Risk Monitoring.

Beginning with the first point of phase one is the risk identification, which is considered as fundamental stage of the entire risk management process. This involves a comprehensive and structured determination of potential SC risks associated with the given problem. The main focus of supply chain risk identification is to recognize SC uncertainties in order to enable an efficient risk management (Hallikas et al., 2000; Norrman and Jansson, 2004; Kleindorfer and Saad, 2005; Cucchiella and Gastaldi, 2006; Ritchie and Brindley, 2007; Pujawan and Geraldin, 2009; Blome and Schoenherr, 2011; Kern et al., 2012; Ghadge et al., 2013; Ceryno et al., 2014).

A large number of techniques exist for Risk Identification, such as brainstorming and workshops (Harland et al., 2003; Oehnen et al., 2009; Elleuch et al., 2014), Failure Checklists (Chase et al., 2006; Tummala and Schoenherr, 2011), survey and interviews (Shen et al, 2001; Hallikas et al., 2002; Hallikas et al., 2004; Lee et al., 2007; Tuncel and Alpan 2010), Delphi groups (Ghadge et al., 2013), Risk Mapping (Gardner and Cooper, 2003; Norrman and Jansson, 2004; Pujawan and Geraldin, 2009; Tummala and Schoenherr, 2011), Value-Focused Process Engineering (VFPE) (Neiger et al., 2007); KPI monitoring (Giannakis and Louis, 2011) and various diagramming approaches such as Cause-Effect diagrams (Tummala et al., 1994; Chase et al., 2006), Failure Tree Analysis (FTA) and Event Tree Analysis (ETA) (Tummala and Schoenherr, 2011), Failure Mode And Effect Analysis (FMEA) (McDermott et al., 1996; Karim et al., 2008; Tuncel and Alpan 2010; Tummala and Schoenherr, 2011; Elleuch et al., 2014) and Influence Diagrams (Chapman, 1997; Hollnagel, 2004).

According to Mojtahedi et al. (2008) there is not a "best method" for risk identification. Shen et al. (2001), Hallikas et al. (2002), Chapman and Ward (2003), Harland et al. (2003), Oehnen et al. (2009) suggest the directed-thinking approach for identifying specific risks, which includes activities such as the 
interviewing or surveying individuals or groups, brainstorming, and using checklists.

Risk assessment is the second step for SCRM, which focuses on the prioritization of the risks that will affect the vulnerability of the SC, as consequence contributes with the selection process of suitable corrective management actions for the identified risk in the Risk Identification phase (Harland et al., 2003; Hallikas et al., 2004; Norrman and Jansson, 2004; Adhitya et al., 2008; Oehnen et al., 2009; Giannakis and Louis, 2011; Blome and Schoenherr, 2011; Tummala and Schoenherr, 2011; Elleuch et al., 2014). Many authors define risk assessment as the determination of the likelihood of occurrence and severity level for each risk identified (Hallikas et al., 2002; Hallikas et al., 2002; Harland et al., 2003; Norrman and Jansson, 2004; Kleindorfer and Saad, 2005; Ritchie and Brindley, 2007; Adhitya et al., 2008; Manuj and Mentzer, 2008; Oehnen et al., 2009; Tuncel and Alpan, 2010; Blome and Schoenherr, 2011; Giannakis and Louis, 2011; Tummala and Schoenherr, 2011; Kern et al., 2012; Ghadge et al., 2013).

When dealing with project environments, Ward (1999) suggested that risks should be prioritized based on an assessment of a probability and severity matrix. The specific combinations of probability and impact leads to a risk rating of "high," "moderate," or "low" and aims at selecting an adequate risk management process for the rated risks. The results from a risk probability and severity matrix also contribute for a risk profile picturing.

As noted on risk identification, the literature also offers many tools for risk assessment. Assessing risks into a probability and severity matrix are largely adopted, as seen in methods by Deloach (2000), Hallikas et al. (2004), Norrman and Jansson (2004), Thun and Hoenig (2009) and Dey (2010). These authors also referred to this method as risk map/matrix assessment.

Last stage for phase I of SCRM process is the Risk Evaluation. According to Tummala and Schoenherr (2011), Risk Evaluation includes two sub-steps of risk ranking and risk acceptance. Common definition for risk ranking is the expression of probability x severity (The Royal Society, 1992; Deloach, 2000; 
Wittmann, 2000; Shen et al. 2001; Tummala and Mak, 2001; Wang and Liu 2004; Zhou et al., 2007; Thun and Hoenig, 2009; Dey, 2010; Tummala and Schoenherr, 2011). Risk ranking determine the risk exposure level for each one identified and assessed (Tummala and Schoenherr, 2011). In order to construct a risk map/matrix it is preceded a risk ranking process (Deloach, 2000; Wittmann, 2000; Hallikas et al., 2004; Norrman and Jansson, 2004; Thun and Hoenig, 2009; Dey, 2010). Once the SC risks are classified, acceptable levels of risk must be established, which is performed in the risk acceptance step.

Finally, phase II of SCRM process is based on the risk mitigation plan and control (Figure 8). Tummala and Schoenherr (2011) indicated that risk mitigation involves the development of risk response action plans to contain and treat risks (risk planning), while risk control and monitoring consists on examining of the progress made regarding the implemented risk treatment strategies and corrective actions that can be taken if deviations occur in achieving the desired SC performance (Norrman and Jansson, 2004; Oehnen et al., 2009; Tummala and Schoenherr, 2011; Kern et al., 2012).

\section{3. \\ Shipbuilding risks}

The literature presents a lack of empirical research in the shipbuilding industry (Mentzer et al., 2001; Lee et al., 2007; Arica and Alfnes, 2012; Gunasekaran, and Spalanzani, 2012). However, for risk assessments there are some studies carried out, englobing mathematical modeling and statistical approaches to cost and schedule, as well as simulation methods, among others.

As for statistical approach, Both Lee et al. (2009) and Basuki et al. (2010) identify risks in shipbuilding using a Bayesian network. A Bayesian belief network, also called a causal network or belief network, is a powerful tool for knowledge representation and reasoning under conditions of uncertainty (Cheng et al., 2002), and visually presents the probabilistic relationships among a set of variables (Heckerman, 1997). Although the Bayesian belief network has many advantages, one of this method drawback is to require continuous variables to be discretized (Uusitalo, 2007). In an analysis including continuous variables, the need to be transformed to discretize variables could bring to information loss. 
Basuki et al. (2010) used the Bayesian network with the assistance of a probabilistic Value At Risk (VaR) in order to analyze every node of the model. Overall, the major risks identified in both studies were design change, raw material supply and production risks related to hull construction process, as with highest probability of causing project delays.

Duffey and Van Dorp (1999) analyze risk for the design and contracting stages of large engineering projects using a Monte Carlo simulation. In this method, the risk analysis integrate schedule and cost information using activity networks and simulation iterations with Monte Carlo approach to quantify the uncertainty in the project as costs. During design stages main risks were identified, such as: determining firm fixed-price bids, complex make-or-buy subcontracting decisions, evaluation of different production process design alternatives, and others. Other related risk issues observed by Duffey and Van Dorp (1999) are engineering change orders and rework. The Monte Carlo methodology has some limitation in regards to the activity network used. In this methodology, the activity network has a deterministic structure, which presumes that all activities in the network will performed one time only during the project. This can be more questionable for highly concurrent processes that include both product and process design innovations.

Floriano et al. (2010) developed a process for identification and analyses of risks in the Brazilian shipbuilding industry environment through methods of brainstorming and Delphi. His work included the participation of experts from various segments of the shipping industry, members of classification societies, yards, shipowners and scholars from the area of education and research. He presented an Analytical Risk Framework (ARF) for the project divided into seven levels: External factors, Funding, Procurement, Planning, Design, Construction and Marketing. The Construction item was further subdivided into three sublevels: Technology, Infrastructure and Human resources. In this way, the risks were classified into these categories and also evaluated according to the probability of occurrence and the severity of impact on the project schedule and budget. As a result, each risk was rated according to their level of criticality for each construction phase. Queiroz (2012) also used the method of Analytical Risk 
Framework (ARF) in order to identify the risks associated with naval construction. However, his study is a comparative analysis of project risks shipbuilding in Brazil, from the point of view of shipowners and as financial institutions. As a result, it presents a risk rating-yard based on credit rating evaluation, which is organized hierarchically according to AHP method.

Goldberg et al. (2010) proposed a methodology that qualitatively assesses the main risks as to the probability and severity, and rank by relevance. These risks are classified in three classes (demand, country and project), and subclasses, shown in Figure 5.

Figure 5 - Shipbuilding risks types

\begin{tabular}{|c|c|}
\hline $\begin{array}{l}\text { Demand } \\
\text { Risk }\end{array}$ & $\begin{array}{l}\text { - Offshore orders and others } \\
\text { segments }\end{array}$ \\
\hline $\begin{array}{l}\text { Country } \\
\text { Risk }\end{array}$ & $\begin{array}{l}\text { - Legal } \\
\text { - Political } \\
\text { - Moneteray } \\
\text { - Force majure }\end{array}$ \\
\hline $\begin{array}{l}\text { Project } \\
\text { Risk }\end{array}$ & $\begin{array}{l}\text { - Construction } \\
\text { •Operational } \\
\text { - Financial }\end{array}$ \\
\hline
\end{tabular}

Source: Goldberg et al. (2010)

Lee et al (2007) analyzed the critical risks in the Korean shipbuilding industry, identifying and evaluating them according to their relationships with phases of construction. He conducted a survey of 248 respondents from 10 major Korean shipbuilders and presented a list of 26 risks, as follows:

1. Typhoon, flood, earthquake and other uncontrollable events happen.

2. Regulations against shipbuilders tighten or are amended

3. Classification's rules change and influence shipbuilders.

4. Incendiary fire or burglaries occur.

5. There is difficulty in supply of raw materials.

6. Labor costs rise and cause problems.

7. There is difficulty in meeting labor demands for production. 
8. There is difficulty in supplying production equipment.

9. Unexpected changes in inflation occur.

10. New taxes or big changes in tax rates occur.

11. Unexpected changes in exchange rates occur.

12. Unexpected changes in interest rates occur.

13. Changes in company credit ratings occur.

14. Refund guarantee, operating costs, and other difficulties in capital funding.

15. Unexpected difficulties in cash flow occur.

16. There are shortages in design manpower.

17. Changes in design occur.

18. Introduction of new technologies incur new risks.

19. Failures in production equipment occur.

20. Instances arise where specifications of the contract cannot be met.

21. Productivity does not improve.

22. Problems in quality management arise.

23. Problems arise due to strikes at headquarters.

24. Problems arise due to strikes at subcontractors.

25. Time schedule is exceeded and does not go according to plan.

26. Budget is exceeded and does not go according to plan.

Lee et al. (2007) presented each phase of construction with the main risks associated: At the beginning stage of shipbuilding design and financial risks were related while during the steel manufacture and block assembly, important risk factors were management of production equipment, supply of raw materials and labor, and quality management. During a more advance stage of production, risks such as changes in design and managerial risks such as exceeding time and budget limits proved to be important. Finally, according to Lee et al. (2007) at the project finalization, phase risks were exchange rates, interest rates, timeline, fulfilling specifications, and natural disasters.

Lee et al. (2007) have an important overview of the risks in shipbuilding, which study was a result from an extensive survey in the Korean Shipbuilding. As for the purpose of this study, Lee et al. (2007) 26 listed risks was applied as an 
initial step to identify and assess the risks in the Brazilian shipbuilding. As will be reviewed in the methodology section, the 26 risks were first assessed through a survey approach with main shipbuilders in Brazil. 


\section{4.}

\section{Shipbuilding overview}

This section brings an overlook on the shipbuilding from different aspects, starting with a general introduction to the industry, its main actors, the main macro process and activity costs, and finally a global market overview. The main goal is to analyze the relationship of shipbuilding supply chain from its main actors and processes as well as to understand uncertainties and the behavior of this activity in a global market scale.

\section{1.}

\section{Shipbuilding industry}

The shipbuilding industry is basically surrounded by two types of other industries: front industries, which include maritime transportation and supply service, fishery and defense; and backward industries, which include machinery, electronic parts, steel and other general marine supply, as shown in Figure 6 (Queiroz, 2009; Moura 2008).

Figure 6 - Shipbuilding industry links

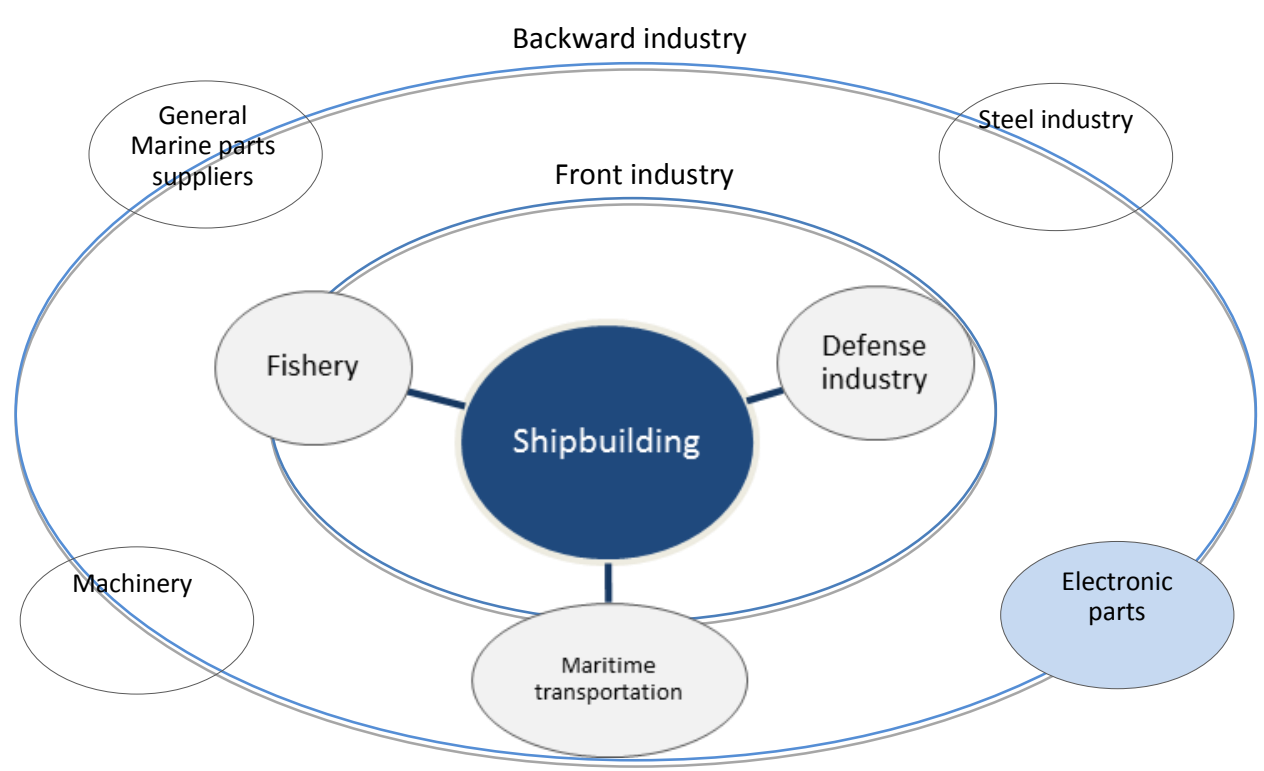

Source: Based on Coutinho (2006) and Moura et al. (2007)

Shipbuilding itself is composed of construction, repair and vessel's scrapping, which all obtain the primary demand from the Front industry. This 
study is focused on construction activity only, which corresponds of almost $90 \%$ of the Brazilian shipbuilding activity (Faverin et al., 2009).

On the other hand, the backward industry is there to supply the shipyards and provide distinctive sorts of materials, from steel plates to small parts such as nut and bolts, to complex machinery and electrical parts. The backward industry is intrinsically connected to the success of the shipbuilding business (Moura et al., 2007).

Based on Olhager (2010), it is also important to investigate the role of the CODP on different industries around the shipbuilding. As observed in section 2.2, the CODP has a key role in developing and managing value chain for upstream and downstream the CODP. For firms where there is only one type of decoupling situation, it applies a single approach for the value chain. Basically, the steel industry follows a MTS structure, which maintain a mass production strategy and keeps an inventory in the distribution system. However, most firms tend to have a mix of MTO and MTS products, based on demand volume and variability, as observed in machinery and electronic parts suppliers. Finally, in ATO situations the two types of approaches need to be applied to different parts of the value chain for a single product line. This is the case for general marine part suppliers.

The important issue is to fit the approach to the task of each material flow both upstream and downstream the CODP. This is seen as a challenge for an ETO that shares many different production strategies as observed in shipbuilding industry, and ultimately is focused on flexibility and lead time reduction (Olhager, 2010).

Nevertheless, the stability of both Front and Backward industries directly affects the shipyards. For example, a disruptive event can take the form of price increases in material parts and equipment from the suppliers, likewise the fall of shipbuilding demand that can dramatically reduce new ship orders. In any of these situations, a serious consequence for the business continuity of the shipyards and the entire shipbuilding industry is on alert (Moura et al., 2007; Queiroz, 2009). Therefore, it seems a great concern to observe the economic scenario and potential risks when studying shipbuilding, further examined in section 4.5. 


\section{2.}

\section{Shipbuilding main actors}

The shipbuilding is centered on two main actors: shipyards and shipowners. They both extend a wide list of relationships with Classification Society (Regulatory, Research \& Education Organizations), Government and Multilateral Institutions (Federal institutions, Transportation Ministry and Unions), raw materials and equipment suppliers, bank institutions, as well as with other shipowners and shipbuilders (Pires, 2004; Queiroz, 2009; Sarderet al., 2010).

Coutinho (2006), Liu and Zhao (2006) and Araujo et al. (2011), presented the main links around the shipyards and shipowners with a more comprehensive and a macro outline of their relationship, with other actors in the shipbuilding chain (see Figure 7).

Figure 7 - Shipbuilding macro Supply Chain

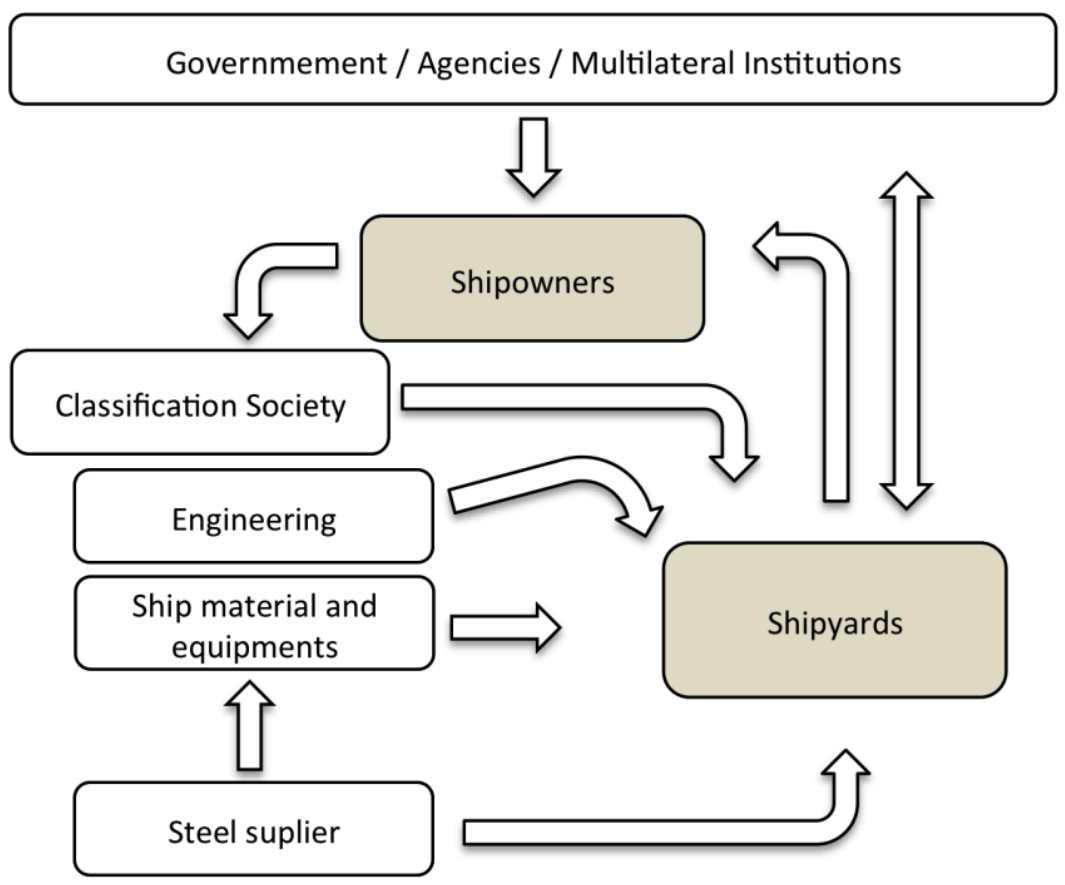

Source: Based on Coutinho, (2006); Liu and Zhao, (2006); Araujo (2011).

Shipowners are extremely important agents in the chain, ranging from small owners with a vessel to carriers with significant fleets. The relationship between the shipowners and the shipbuilding industry is significant as they are the primary 
customers for new vessel's orders (Pires, 2004; Coutinho, 2006; Liu and Zhao 2006). As observed on the previous chapter, the sale of a vessel is considered as the mark of the CODP for an ETO production system as ship construction.

Additionally, multilateral institutions, government and agencies have an important role to support the shipbuilding activity (Liu and Zhao 2006; Sarderet al., 2010). As demonstrate in the Figure 6, they have direct connection with Shipowners and Shipyards.

In the case of Brazil, local government has implement many incentives for the local shipyard production, ranging from taxes exemptions, funding to support ship construction and many protectionism actions to develop local content and build a sustainable and competitive local industry.

Multilateral intuitions can also participate directly or indirectly in the demand of new ship orders (Liu and Zhao, 2006). In the case of Brazil, a major energy company directly contributed to the recovery of the shipping industry. This major energy company has developed several ocean fleet renewal programs and raised numerous new ship orders to supply vessels, oil carriers, oil platforms and others types. (Faverin et al., 2010 a) One of the main reasons for renewing the fleet was also due to booming period of a new type of oil exploration from pre-salt layers. The pre-salt exploration requires modern vessels with higher supply capacity and that are able to sustain longer periods offshore. This is necessary since the distance from the coast to oil platforms expanded and consequently the time for each single voyage also increased, as well as its operational costs. Therefore, to sustain this new oil exploration activity, the vessels needed to be larger and more self-sufficient in order to obtain more gain in scale (Coutinho, 2006; Queiroz, 2009).

The last upstream actor in figure 6 is the Bank institutions, which acts as financial agents granting loans to shipping companies and also to shipyards in order to support new ship constructions (Balance, 2000), as represented with point arrows from bank institutions to shipyards and shipowners in Figure 7. Their role is basically to assume the credit risk of this activity. Due to this risk, banks charge a rate of interest from its beneficiary that can vary from 2.5 to $5 \%$ for the 
construction of ships, which is defined by the Brazilian Monetary Council (Balance, 2000; Queiroz, 2009).

These financing rates are generally progressive, inversely proportional to the local content index, which range between $50 \%$ and $70 \%$ of the sales price of the vessel. In other words, the interest rates vary according to the percentage of local content applied in the ship construction, which local content is basically the amount of materials and equipment used from a local supplier, as well as the quantity of local labor used (Balance, 2000; Kanerva, 2004; Araujo et al., 2011).

The next important actor is the Classification Society, which is a nongovernmental organization that establishes and maintains technical standards for the construction and operation of ships and offshore structures (Coutinho, 2006; Liu and Zhao, 2006).

As represented by the arrow in Figure 7, the Classification Society has a strong relationship with the shipyards and shipowners, since the society is hired by the shipowners to evaluate if a construction is in compliance with the required standards (Pires, 2004; Coutinho, 2006; Liu and Zhao, 2006).

A vessel that has been designed and built according to appropriate Rules of a Society may apply for a certificate of classification from that Society. However, such certificate does not imply, and should not be interpreted as a warranty of safety but to purpose seaworthiness of the ship. It is only certification that the vessel is in compliance with the Rules that have been developed and published by the Society issuing the classification certificate, which is a requirement for the vessel's insurance.

According to Liu and Zhao 2006, the project is developed by a firm of skilled engineers. In this case, the project must be suited to the needs of the owner, the characteristics of ports and routes that will serve, capacity and industrial facilities builder shipyard and by the standards of the classification society. The engineering has also the important role of providing the construction drawings in order to start the shipbuilding activities and also to support the 
specifications for material and equipment to be purchased, which has to follow the production schedule.

Furthermore, there is the steel industry at the bottom of Figure 7, directly supporting the shipyards with steel plates for hull construction, and directly supporting the backward industry with raw materials for ship parts and equipment. Noteworthy, the existence of a developed steel industry substantiates important competitive advantage for a national shipbuilding industry (Pires, 2004; Coutinho, 2006).

As will be explored in the next section, the steel plates used for the hull constructions are responsible for a significant portion of the costs of building a ship. In that case, steel producers have great bargain in the supply chain and upon shipyards (Faverin et al., 2010 a; Queiroz, 2009).

\section{3.}

\section{Shipbuilding macro processes}

Shipbuilding can be divided into two macro processes: Design and Hull Production and Outfitting (Montes, 1993; Lamb, 2003; Favarin, el al., 2010 b; Tancredi et al., 2012). These macro processes are segmented into sub-processes, from the concept of development and contract, to commissioning and delivery, as displayed in Figure 8.

Figure 8 - Shipbuilding processes overview

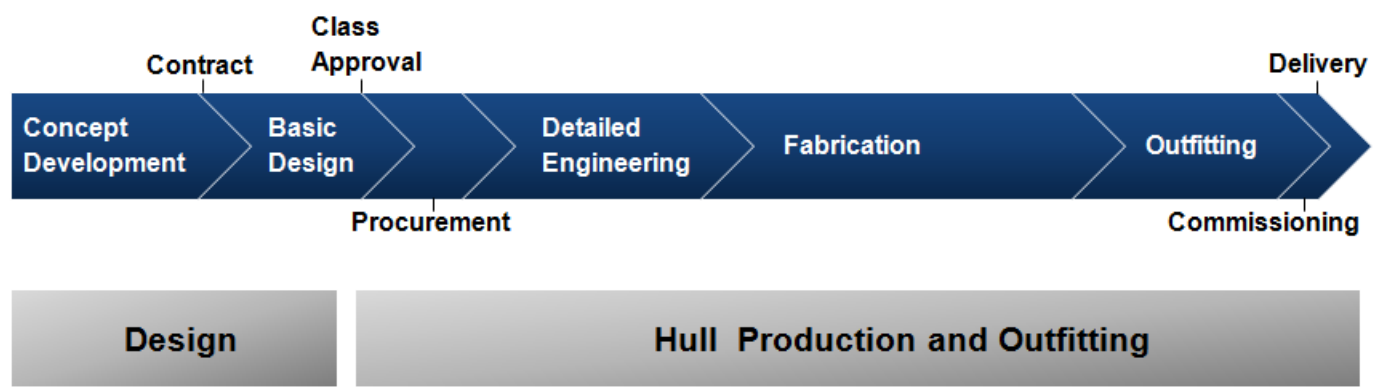

Source: Montes (1993); Lamb (2003); Favarin et al. (2010 b); Tancredi et al. (2012) 
The first phase of the design begins with conceptual development, where the designers and engineers start defining the shape and dimensions of the vessel, as well as its specifications. After modeling the theoretical design, the ship model is tested in a proof tank, being submitted to a variety of conditions that can attest its seaworthiness. The key objective of the concept development is to ensure the feasibility of the project (Fleischer et al., 1999).

One of the main products of the concept development is the General Arrangement that shows, in a determined scale, the drawing showing the inside of a ship and where the main elements are placed. Also in this stage, a document describing the specifications of construction (Build Specification) is provided, which outlines the standards for workmanship and mentions the overall requirements for the functionality of the vessel. Usually the Build Specification includes a Maker's list, and a list of suppliers qualified to provide each type of equipment to be followed by the contract of construction (Favarin et al., $2010 \mathrm{~b}$ ).

After the ship concept is approved, the project of construction can be now ordered to shipyards, and this stage the basic design process initiate. All of the drawings from the design are subjected to a class approval with a classification society. The last stage of the design macro process starts now to overlap to other process.

Commencing now the macro process of Hull production and outfitting, it begins with the procurement process by purchases of structural steel, marine parts such as motors, cranes, caps basement, propellers, navigation equipment etc. Ultimately, this is also when it triggers the start of the detailed engineering.

The hull production takes place by cutting steel plates and assembling vessel hull blocks. This is also referred as the structural part of the vessel and often represents the higher production cost of the shipyard, since this process is the most time consuming, compared to other processes (Tancredi el al., 2012; Eyres, 2007; Lamb, 2003; Favarin et al., 2010 b; Montes 1993).

Defined also as part of the production, the outfitting phase represents the phase where the vessel is equipped with propulsion, support materials such as 
plumbing, electrical installations and etc. In some cases, the hull production and outfitting may also occur simultaneously during the phase of construction (Walter and Ries, 1996).

Finally, at the end of the production process the vessel is submitted to the commission step. Through commissioning, the vessel is assured that all systems and components installed of the vessel are tested according to the construction specification established on the design stage. After approved by commissioning, the vessel is now ready for delivery to the shipowners.

\section{4. \\ Shipbuilding activity costs}

According to Sarderet al. (2010), the start of a ship construction activity is characterized by being a high capital-intensive activity. As shipyards require gigantic facilities such as dorks, goliaths, and cranes, as well as workshops and complex structures for assembling hull part, it is clear that a hefty initial investment is required. This is also shown by the high amount of capital disbursed for the early stages of ship construction to cover the purchase for raw materials (mainly steel plates) and heavy machinery.

The vessel, in general, is considered a product of high value (final price). Depending on the size of the ship by its deadweight tonnage (DWT), the final product may have approximately 300,000 pieces of 2,000 different types (Lamb, 2003; Eyres, 2007).

In this way, the procurement cost is the largest part of the total expenses, which can represent $80 \%$ of the total costs. It has a huge direct impact on the cost and quality of production activities. Therefore, the construction activity expenses involve mainly man-hour expenses and special production expenses (Balance, 2000; Favarin et al., 2006 b; Coutinho, 2006; Queiroz, 2009). 


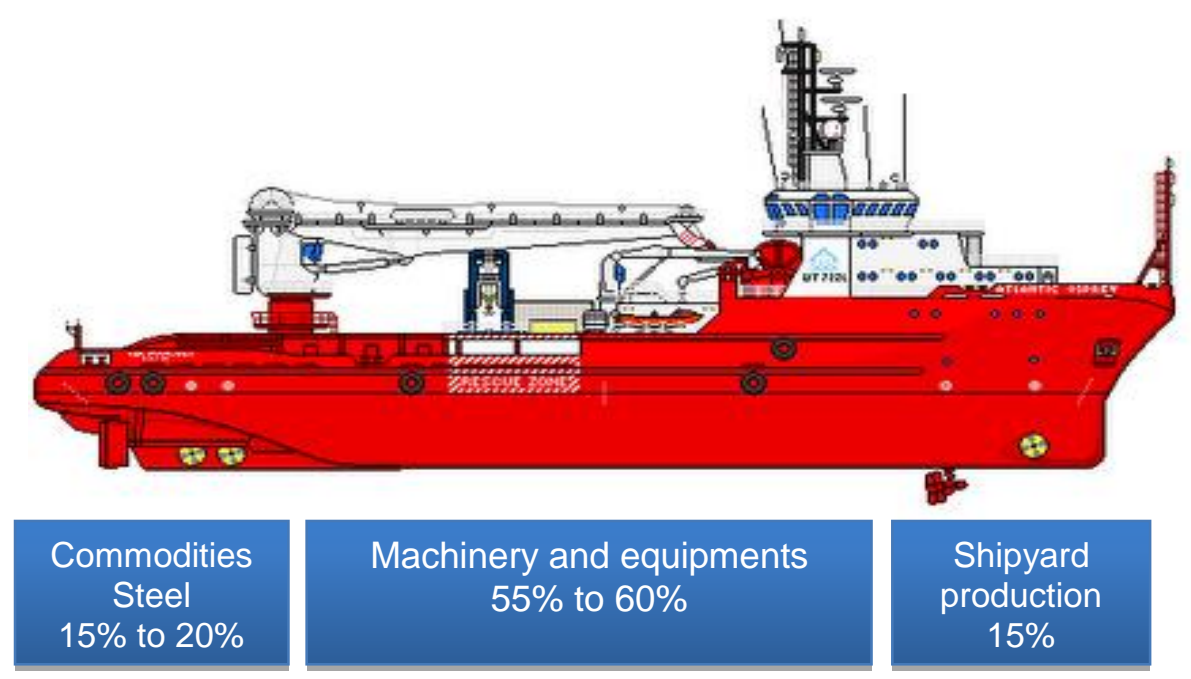

Source: Based on Kanerva (2004); Favarin et al. (2010 b)

As displayed on Figure 9 above, the division for the costs of shipbuilding, are basically: steel, marine parts and workforce (Balance, 2000; Ferraz et al., 2002; Kanerva, 2004; Coutinho, 2006; Queiroz, 2009; Favarin, 2010 b).

\section{5.}

Shipbuilding global market overlook

As mentioned on previous chapter, shipbuilding industries have a direct relationship with the Front and Backward industries. Overall, they are affected by the global demand and economic activity. Basically, whenever the economy is heated, international trade intensifies and ocean freight rises. This can result in a positive trend to many industries, as well as to shipbuilding, that can have an increase in new ship orders in a short time (Stopford, 2005).

However there are many uncertainties that circle around the global market. For shipbuilding industry in particular, there is a typical lag between the actual contract and the delivery of the vessel, which can take 2 to 5 years. In this case, the freight market is absorbed and amplified by the shipbuilding industry, causing a similar "bull whip effect", as in reference to the effect observed in Supply Chains (Liu and Zhao, 2006). Basically, the present demand for a new ship order 
can generate great expectations, in the way that the market will follow the growing demand for the next few years. Conversely, this can create an environment of uncertainty and a tendency to overcapacity, meaning that by the time the order is attended the market may not be as good as expected. Additionally, large improvements in the productivity of the shipyards, over investments in addition to many governmental benefices to this industry can also contribute to this overcapacity by facilitating the ship construction in large scale (Fleisher et al., 1999; Colin and Pinto 2006; Pires Jr. et al, 2007; Paraschiv and Albescu, 2008).

Today, the shipbuilding market worldwide is already suffering from a significant excess capacity. The present ship production shows that Asian countries such as Japan, South Korea and China, was expanded forcefully before the economic crisis by the end of 2008 - for instance, in only a few years, China rose to the largest shipbuilding nation in the world, which account for about $79 \%$ of world production, more than 3,400 vessels in 2014 (as showed in Table 3). Other countries in Europe have lost its market share for the booming of maritime industries in the Far Eastern countries, as well as for Brazil, showing a very timid participation representing only $0.4 \%$ of the world ship's orders (Colin and Pinto 2006; Pires Jr. et al, 2007).

Table 4 - World's new ship orders book

\begin{tabular}{|c|c|c|c|c|c|c|c|c|c|c|c|}
\hline Year & World & Brazil & Brazil Share & USA & USA Share & Europe & Europe Share & China & Korea & Japan & Asia Share \\
\hline 1996 & 1948 & 10 & $0.5 \%$ & 56 & $2.9 \%$ & 329 & $16.9 \%$ & 172 & 316 & 546 & $62.3 \%$ \\
1997 & 2113 & 4 & $0.2 \%$ & 66 & $3.1 \%$ & 279 & $13.2 \%$ & 249 & 295 & 636 & $65.5 \%$ \\
1998 & 2251 & 5 & $0.2 \%$ & 135 & $6.0 \%$ & 265 & $11.8 \%$ & 237 & 302 & 683 & $62.5 \%$ \\
1999 & 2044 & 5 & $0.2 \%$ & 113 & $5.5 \%$ & 251 & $12.3 \%$ & 205 & 305 & 561 & $60.6 \%$ \\
2000 & 1885 & 5 & $0.3 \%$ & 74 & $3.9 \%$ & 226 & $12.0 \%$ & 242 & 357 & 524 & $66.0 \%$ \\
2001 & 2182 & 4 & $0.2 \%$ & 73 & $3.3 \%$ & 238 & $10.9 \%$ & 284 & 513 & 558 & $69.1 \%$ \\
2002 & 2239 & 13 & $0.6 \%$ & 96 & $4.3 \%$ & 217 & $9.7 \%$ & 340 & 479 & 542 & $67.4 \%$ \\
2003 & 2342 & 17 & $0.7 \%$ & 105 & $4.5 \%$ & 181 & $7.7 \%$ & 382 & 484 & 642 & $69.6 \%$ \\
2004 & 3288 & 25 & $0.8 \%$ & 80 & $2.4 \%$ & 201 & $6.1 \%$ & 615 & 785 & 960 & $76.0 \%$ \\
2005 & 4306 & 23 & $0.5 \%$ & 64 & $1.5 \%$ & 253 & $5.9 \%$ & 938 & 1014 & 1127 & $75.1 \%$ \\
2006 & 5521 & 26 & $0.5 \%$ & 85 & $1.5 \%$ & 336 & $6.1 \%$ & 1366 & 1123 & 1309 & $73.5 \%$ \\
2007 & 7558 & 35 & $0.5 \%$ & 145 & $1.9 \%$ & 349 & $4.6 \%$ & 2339 & 1456 & 1557 & $74.3 \%$ \\
2008 & 10557 & 60 & $0.6 \%$ & 174 & $1.6 \%$ & 363 & $3.4 \%$ & 3847 & 2211 & 1834 & $77.1 \%$ \\
2009 & 11074 & 75 & $0.7 \%$ & 143 & $1.3 \%$ & 339 & $3.1 \%$ & 4330 & 2292 & 1886 & $78.7 \%$ \\
2010 & 9198 & 74 & $0.8 \%$ & 83 & $0.9 \%$ & 258 & $2.8 \%$ & 3862 & 1826 & 1517 & $79.8 \%$ \\
2011 & 8447 & 102 & $1.2 \%$ & 69 & $0.8 \%$ & 206 & $2.4 \%$ & 3825 & 1543 & 1324 & $80.0 \%$ \\
2012 & 6785 & 135 & $2.0 \%$ & 90 & $1.3 \%$ & 194 & $2.9 \%$ & 3023 & 1152 & 1045 & $77.8 \%$ \\
2013 & 5113 & 162 & $3.2 \%$ & 111 & $2.2 \%$ & 116 & $2.3 \%$ & 2101 & 839 & 837 & $74.8 \%$ \\
2014 & 5535 & 148 & $2.7 \%$ & 123 & $2.2 \%$ & 85 & $1.5 \%$ & 2441 & 926 & 989 & $79.4 \%$ \\
\hline
\end{tabular}

Source: Clarkson's Shipping Intelligence (2014) 
As demonstrated into Figure 10, the excess of capacity is observed after the economic crises of 2008, which also dramatically decreased new ship orders. The Figure 7 shows the described delay on the industry from the time that the economic crises hit the market and the time that the demand has dropped. It was only in mid 2009 that ship orders started to plunge. In 2013, four years later, total ship orders had dramatically fallen to about 5,000, less than half the 2009 total of about 11,000 ship orders (Faverin et al., 2009; Queiroz, 2009).

Figure 10 - World's new ship orders

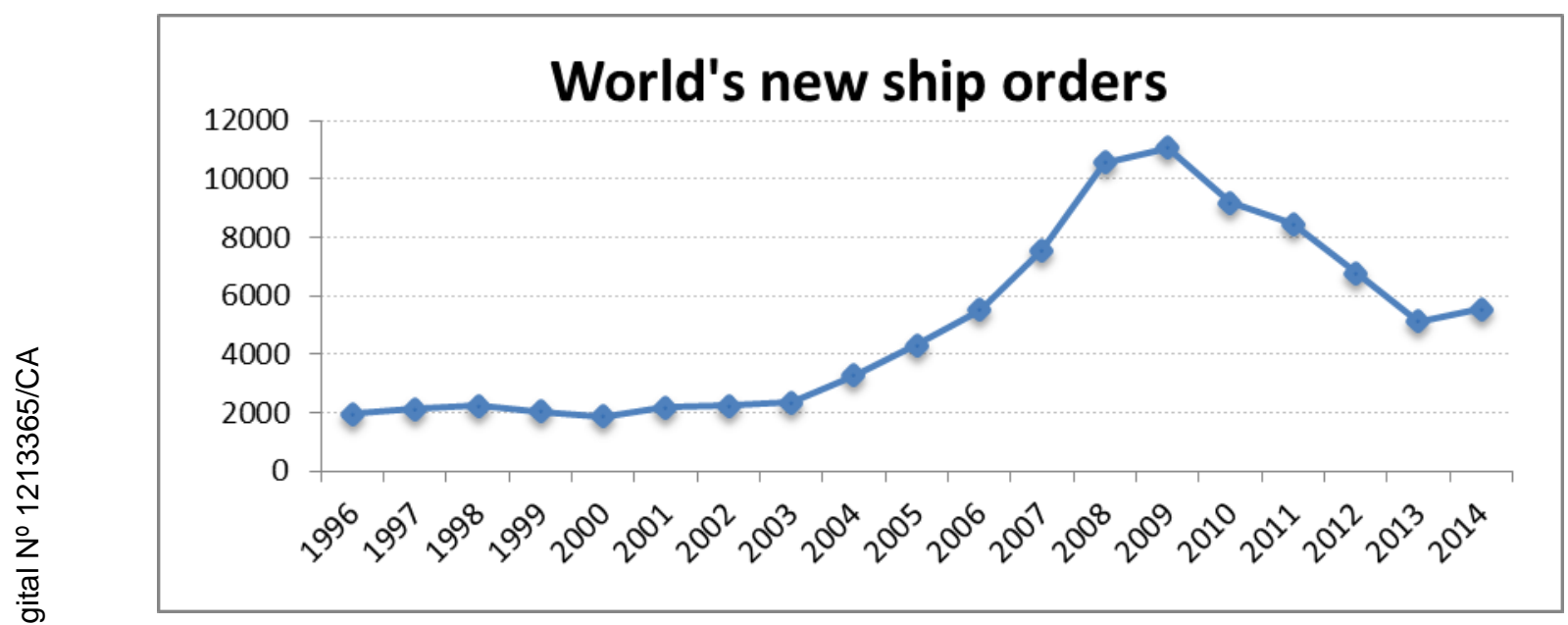

Source: Clarkson's Shipping Intelligence (2014)

Overall, an imbalance between supply and demand in shipbuilding has also affected shipping markets since so much new tonnage is entering the market. Although the demand for shipping services has been growing after the economic downturn, the fleet oversupply is still overrunning the cargo growth and the future demand ship's orders remains uncertain. 


\section{5. \\ Research design and methodology}

The research method adopted was based on a survey approach. A survey was conducted in order to identify and examine risks in shipbuilding supply chain, considering the Brazilian industry. The choice for the Brazilian shipbuilding industry was motivated by the fact that there are few studies regarding risk management in literature. The lack of empirical research became even more crucial since this industry has experienced a long period of stagnation (Kanerva, 2004; Colin and Pinto, 2006; Queiroz, 2012). This necessity of empirical evidence offers a great opportunity for research in SCRM in shipbuilding as well as a great interest in risk profile in this industry for both practitioners and academics.

The survey method was based on three Rounds, in order to cover all steps of the first phase of the SCRM process, which this study is focused on. The last Round of the survey took place to discuss and analyze the results with the respondents. These processes are represented in figure 11 .

Figure 11 - Methodology summary

SCRM Process Phase I - Risk Analysis

\begin{tabular}{|c|c|c|c|}
\hline Risk identification and Assessment & Risk Evaluation \\
\hline Survey Round I & Results and discussion \\
\hline Survey Round II & Data treatment & Risk map/matrix Risk ranking \\
\hline
\end{tabular}

In Risk Identification and Assessment step, the Round 1 and 2 consisted on the identification of (i) the main risks presented in the Brazilian shipbuilding industry (ii) the likelihood of occurrence (iii) their severity and finally (iv) phase of construction that is associated. These phases were based on Lee et al. (2007), where Phase I of construction is described from contract phase until the steel processing; Phase II of construction is defined by the production period of assembly steel blocks and blocks building into the slipway area; Phase III of construction represents the launching phase of the vessel on the water until advanced outfitting completion; and finally, Phase IV is from commissioning process until delivery 
As observed in Chapter 3, assessing risks by their likelihood and severity is a common method in the literature (The Royal Society, 1992; Deloach, 2000; Thummala and Mak, 2001; Wand and Liu, 2004; Hallikas et al., 2004; Norrman and Jansson, 2004). This also initiates the data treatment step for the Risk Evaluation process. In the first Round, the identification step started from a list based on the 26 risks offered by Lee et al. (2007), recognized in the South Korean Shipbuilding industry. The likelihood of their occurrence and their severity were associated to a three point scale offered in Shen et al. (2001), "highly likely", "likely", "less likely" for likelihood and "high magnitude", "medium magnitude" and "low magnitude" for severity. Round 1 also offered a space to include additional risks that were not included in Lee et al. (2007), but could be representative to the Brazilian Industry. Additional four risks were obtained as the scope of Round 2. This new Round aimed to identify the likelihood of occurrence of these new risks and their severity using the same three point scale from Round 1. Finally, Round 3 consisted in recognizing the main sources and impacts for the top listed risks, as well for mitigation plan adopted or actions required for controlling them. The respondents in Round 3 could also state any complementary opinion or comment for the result presented by Round 1 and 2. Appendix 1 presents the questionnaire used for Round 1, while Appendix 2 presents the one used for Round 3.

The Brazilian shipbuilding industry counts with 32 shipyards (Sinaval, 2014). The shipyards in this survey were selected according to their steel processing capacity per year, a common measurement indicator for this industry. This research included the major shipbuilders considering their steel processing capacity. Nineteen shipyards were chosen covering around $91 \%$ of the total of steel processing capacity in Brazil.

Executives from the selected shipyards were then reached directly once a contact already existed, and indirectly by a common connection, when there were no direct contact. The executives were asked to appoint one expert in their shipyard, considered in his point of view, as a good respondent for the survey. This approach assisted the selection of the appropriate respondent(s) from the company to take part of the survey. Twenty-two respondents from seventeen 
shipyards responded to Round 1 of the survey. The survey obtained a valid response rate of almost 73\%, which is very assertive according to Moser and Kalton (1971). Together, these 17 shipyards covered $85 \%$ of the total of steel processing capacity in Brazil, what results in a representative sample of the industry for the research.

Based on Shen et al. (2001) Wang and Liu (2004) and Zou et al. (2007) the three point scale used in Rounds 1 and 2 was associated to numerical values, where "highly likely" and "high magnitude" corresponded to a value of 1, "likely" and "medium magnitude" corresponded to 0.5 and "less likely" or low magnitude" corresponded to 0.1. Following the Risk Evaluation process, the data gathered was also treated by removing outliers.

There has been much debate in the literature regarding what to do with extreme or influential data points. Outliers can arise from several different mechanisms or causes. Anscombe (1960) sorts outliers into two major categories: those arising from errors in the data, and those arising from the inherent variability of the data. According to Osborne and Overbay (2004), outliers are often caused by human error or different assumptions from the rest of the sample population. Although some authors argue that removal of extreme scores produces undesirable outcomes, they are in the minority, especially when the outliers are illegitimate. Orr et al. (1991) states that the dataset are suspected of being legitimate and more likely to be representative of the population as a whole if outliers are not removed. Conceptually, there are strong arguments for removal or alteration of outliers. As Osborne and Overbay (2004) empirically have demonstrated the benefits of outlier removal, this study have proceeded with this data treatment.

The most common method is the identification and removal of outlier using the mean plus or minus three Standard Deviation (SD) (Miller, 1991; Howell, 1998; McClelland, 2000; Leys et al. 2012). However, three problems can be identified when using Standard Deviation method. First, it assumes that the distribution is normal (outliers included); Second, standard deviation is strongly impacted by outliers; and third, this method is very unlikely to detect outliers in small samples (Miller, 1991; Cousineau and Chartier 2010; Leys et al. 2012). An 
alternative method, which is totally immune to the sample size, is based on the absolute deviation from the median, referred as MAD (median absolute deviation). This method was proposed by Hampel (1974) and popularized as Hampel's test, which is considered one of the basic robust statistical techniques. In this method, the median (M) is, like the mean, a measure of central tendency but offers the advantage of being very insensitive to the presence of outliers. In this general form, the central point can be the mean, median mode or the result of another measure of central tendency (Huber, 1981; Rousseeuw and Croux, 1993; Leys et al., 2011).

Considering the characteristics of the data set of this study, the method MAD using the mean as central tendency was selected as a technique to identify and remove outliers. In this case, the MAD can be calculated by the following equation (1):

$$
\frac{1}{n} \sum_{i=1}^{n}\left|x_{i}-\mu(X)\right|
$$

Where $n=$ total number of observations; $\mathrm{i}=$ ordinal number of the observation; $x_{i}=$ is the original $\mathrm{n}$ observation; and $\mu(X)=$ is the mean of the series.

The approach to the MAD method is similar to the SD when calculating the intervals of the outliers. According to Miller (1991) the values for plus or minus MAD depends on the research criteria. The values can range from 3 (very conservative), 2.5 (moderately conservative) or even 2 (less conservative). The MAD method can be described as below eq (2).

3 MAD method: $C \pm 3$ MAD

2.5 MAD method: $C \pm 2.5 \mathrm{MAD}$

2 MAD method: $C \pm 2 M A D$

Where $C=$ Central tendency (median, mean or mode)

For this study, the method of 2 MAD was selected due to the small variance of the data set (3 point scale from $0.1,0.5$ or 1 ). 
After removing outliers, a clear recognition of the main risks was obtained by a risk assessment from data-set obtained in Rounds 1 and 2 of the survey. This technique supports the constructing of a risk profile for the Brazilian shipbuilding industry. The risk assessment was done based on the risk map/matrix from Deloach (2000), Wittmann (2000) Hallikas et al. (2004), Norrman and Jansson (2004), Thun and Hoenig (2009) and Dey (2010). According to Deloach (2000), Wittmann (2000) and Dey (2010), the risks in the map/matrix can be also classified into groups levels of "probability" and "severity" through a risk ranking method.

According to Dey (2010), the score of the probability versus severity can derive the risk map/matrix into groups of risk exposure levels. For this matrix, the $\mathrm{x}$-axis represents probability/likelihood of risk occurrence and the $\mathrm{y}$-axis represents severity of risk impact (Deloach, 2000; Wittmann, 2000; Dey, 2010). Dey (2010) divides these axes by 5 points intervals. In the index used from Shen et al. (2001), where low index is 0.1 and high index is 1 , this scale were divided into 5 points by intervals of 0.25 .

Figure 10 shows the groups of risks used in the research from the result score of axis- $x$ by axis-y scale. As for example the square at the northeast corner correspond the number 1 as it is the score by likelihood scale 1 versus severity scale 1. Similarly, the central square is represented as 0.25 , from likelihood scale 0.5 versus impact scale 0.5. Based on Deloach (2000), Norrman and Jansson (2004) and Thun and Hoenig (2009), each group risk requires an action of mitigation plan, as also demonstrated in Figure 12. 
Figure 12 - Risk map/matrix groups and actions remove

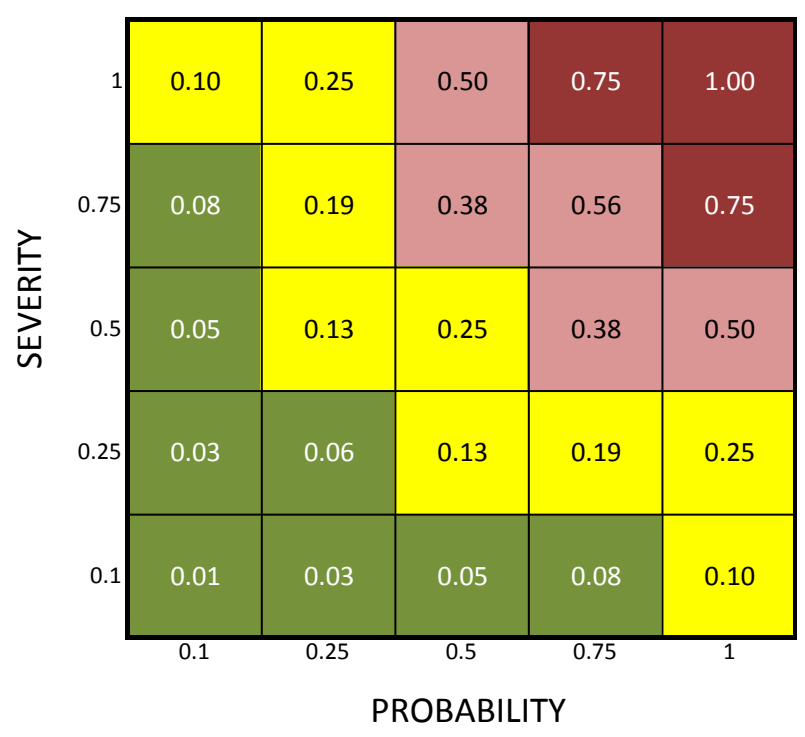

\begin{tabular}{|c|l|}
\hline RISK LEVEL & \multicolumn{1}{c|}{ ACTION REQUIRED } \\
\hline VERY HIGH & $\begin{array}{l}\text { Risk mitigation is required.If the risk is not } \\
\text { mitigated monitoring and making a } \\
\text { contingency plan is necessary. }\end{array}$ \\
\hline HIGH & $\begin{array}{l}\text { Risk mitigation is optional but a monitoring is } \\
\text { required. }\end{array}$ \\
\hline MEDIUM & No further risk mitigation is required \\
\hline LOW &
\end{tabular}

Once establishing the risk map/matrix and each group interval, the risks were populated in the matrix according to the average value for their probability and severity. In order to compare results with another ranking method, the approach of a risk index proposed by Shen et al. (2001) was also used. In Shen et al. (2001) method can be calculated through Eq.(2) below:

$$
R_{i}=\frac{\sum_{j=1}^{n} r_{i j}}{n}=\frac{1}{n} \sum_{j=1}^{n} \alpha_{i j} \beta_{i j}
$$

Where $R_{i}=$ average score for each risk; $r_{i j}=$ significance score assessed by respondent $\mathrm{j}$ for the risk severity $\mathrm{i} ; \mathrm{i}=$ ordinal number of risk, $\mathrm{i} \in(1, \mathrm{~m}) ; \mathrm{m}=$ total number of risks; $\mathrm{j}=$ ordinal number of valid feedback to risk $\mathrm{i}, \mathrm{j} \in(1, \mathrm{n}) ; \mathrm{n}$ $=$ total number of valid feedbacks to risk $\mathrm{i} ; \alpha_{\mathrm{ij}}=$ likelihood occurrence of risk $\mathrm{i}$, assessed by respondent ij; $\beta_{i j}=$ level of consequence of risk $\mathrm{i}$ assessed by respondent j. From Shen et al. (2001) method the results are demonstrated with the risks ordered from the highest risk index to the lowest, as calculated in Equation 3. As part of the risk evaluation process, based on Lee et al. (2009), risks are also categorized from areas influence (political, economic, technical, managerial, legal, social or natural) and also by environment (internal or external). 
Finally, Round 3 surveyed the respondents (based on Appendix 2) in order to evaluate the results from Round 1 and 2. At this point, a discussion about mitigation plans adopted by the shipyards is conducted, as well as further actions and main causes for the risks identified. Moreover, a comparison is made with the results obtained by Lee et al. (2007).

As observed in this section, the methodology can be now described into the following processes as shown on Figure 13.

Figure 13 - Methodology expanded overview

SCRM Process Phase I-Risk Analysis

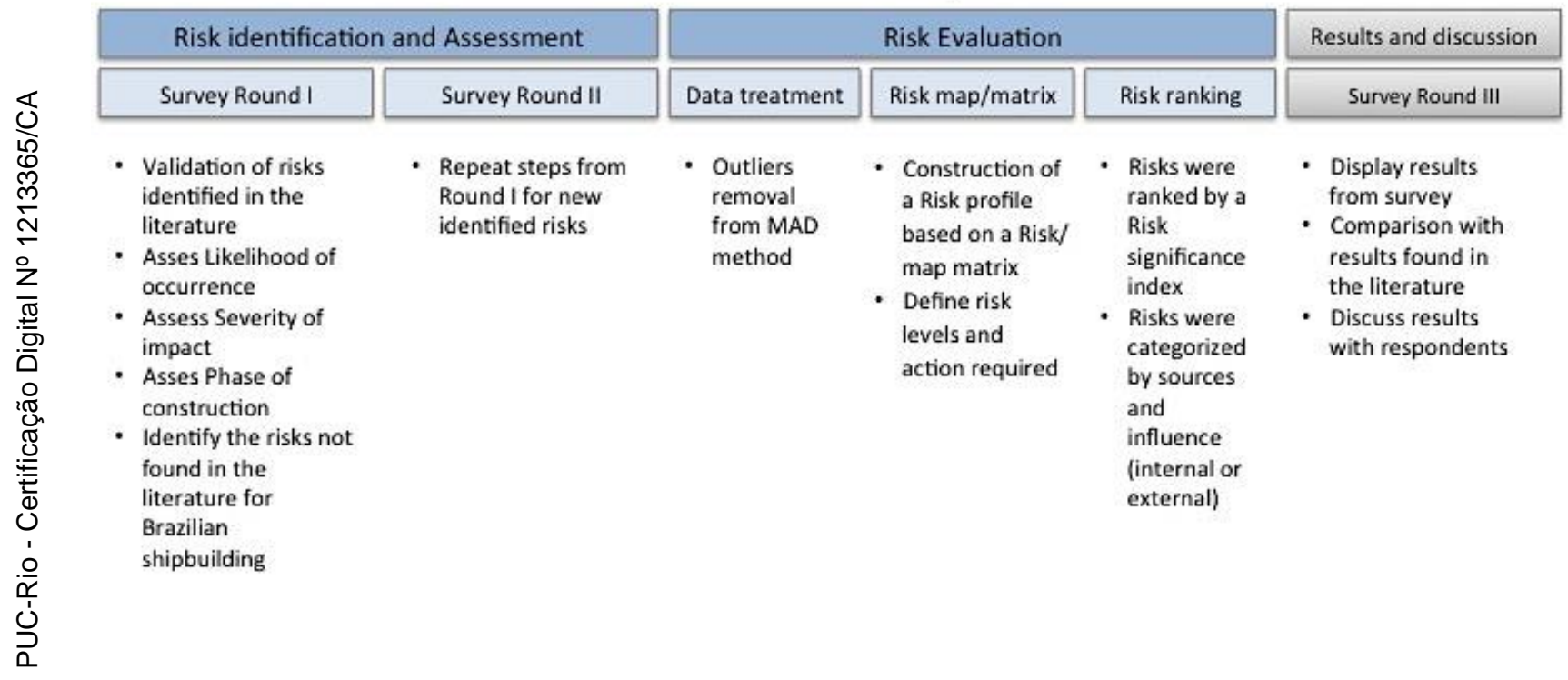




\section{6. \\ Results and discussion}

The results obtained in this research outline the potential risks that the shipbuilding industry is facing and how it can be globally competitive among major players, such as Asian shipyards. Hence, the results found are also compared to the results on Lee et al. (2007) from Korean Shipyard.

Table 5 below displays the finding of Rounds 1 and 2 of this research survey, based on the validation of each risk by 22 respondents and by phase of construction. This is the first step of the SCRM process, presenting the identification of potential risks in the Brazilian shipbuilding industry. From a total of 30 risks, at least 17 risks were validated by the 22 respondents, indicating with a good percentage of replies that all risks are valid for the Brazilian shipbuilding industry (at least by 17 respondents).

As defined in this research methodology, each risk was associated in any of the four phases of construction. In this case, Table 5 shows the quantity of each risk that according to the respondents is presented into a phases of construction. Note that a single respondent is able to appoint a risk in more than one phase of construction and also not all respondents have validated the risks to be relevant for the industry, likewise to a specific phase.

The risks numbered from 1 to 26 are the risks identified in the literature by Lee et al. (2007), and subsequently the risks numbered from 27 to 30 are the additional risks identified by the respondents as relevant to the Brazilian shipbuilding. The four new risks identified were:

27. Discontinuity of incentive programs by local government

28. Decline in demand for new vessels

29. Bankruptcy of local suppliers

30. Delays in construction due to lack of licenses required. 
Table 5 - Main risks in Brazilian shipbuilding industry

\begin{tabular}{|c|c|c|c|c|c|c|}
\hline \multicolumn{7}{|c|}{ Risk Identification } \\
\hline \multirow{2}{*}{ \# } & \multirow{2}{*}{ Risk } & \multirow{2}{*}{$\begin{array}{c}\text { Validation } \\
\mathrm{Y} / \mathrm{N}\end{array}$} & \multicolumn{4}{|c|}{ Phases of construction indication } \\
\hline & & & 1 & II & III & IV \\
\hline 1 & Typhoon, flood, earthquake and other uncontrollable events happen. & 19 & 15 of 19 & 15 of 19 & 15 of 19 & 15 of 19 \\
\hline 2 & Regulations against shipbuilders tighten or are amended & 22 & 20 of 22 & 10 of 22 & 10 of 22 & 7 of 22 \\
\hline 3 & Classification's rules change and influence shipbuilders. & 22 & 17 of 22 & 16 of 22 & 15 of 22 & 12 of 22 \\
\hline 4 & Incendiary fire or burglaries occur. & 17 & 12 of 17 & 15 of 17 & 15 of 17 & 15 of 17 \\
\hline 5 & There is difficulty in supply of raw materials. & 21 & 13 of 21 & 13 of 21 & 14 of 21 & 14 of 21 \\
\hline 6 & Labor costs rise and cause problems. & 22 & 5 of 22 & 21 of 22 & 21 of 22 & 9 of 22 \\
\hline 7 & There is difficulty in meeting labor demands for production. & 22 & 3 of 22 & 21 of 22 & 21 of 22 & 9 of 22 \\
\hline 8 & There is difficulty in supplying production equipment. & 22 & 2 of 22 & 11 of 22 & 22 of 22 & 15 of 22 \\
\hline 9 & Unexpected changes in inflation occur. & 21 & 20 of 21 & 14 of 21 & 14 of 21 & 11 of 21 \\
\hline 10 & New taxes or big changes in tax rates occur. & 21 & 20 of 21 & 16 of 21 & 16 of 21 & 12 of 21 \\
\hline 11 & Unexpected changes in exchange rates occur. & 21 & 20 of 21 & 16 of 21 & 16 of 21 & 13 of 21 \\
\hline 12 & Unexpected changes in interest rates occur. & 22 & 18 of 22 & 2 of 22 & 1 of 22 & 1 of 22 \\
\hline 13 & Changes in company credit ratings occur. & 22 & 20 of 22 & 5 of 22 & 4 of 22 & 1 of 22 \\
\hline 14 & Refund guarantee, operating costs, and other difficulties in capital funding occur. & 22 & 21 of 22 & 7 of 22 & 4 of 22 & 3 of 22 \\
\hline 15 & Unexpected difficulties in cash flow occur. & 22 & 18 of 22 & 21 of 22 & 21 of 22 & 18 of 22 \\
\hline 16 & There are shortages in design manpower. & 22 & 10 of 22 & 20 of 22 & 17 of 22 & 7 of 22 \\
\hline 17 & Changes in design occur. & 22 & 7 of 22 & 21 of 22 & 18 of 22 & 4 of 22 \\
\hline 18 & Introduction of new technologies incur new risks. & 22 & 18 of 22 & 15 of 22 & 15 of 22 & 13 of 22 \\
\hline 19 & Failures in production equipment occur. & 22 & 17 of 22 & 22 of 22 & 20 of 22 & 16 of 22 \\
\hline 20 & Instances arise where the specifications of the shipbuilding contract cannot be met. & 22 & 3 of 22 & 11 of 22 & 10 of 22 & 13 of 22 \\
\hline 21 & Productivity does not improve. & 22 & 4 of 22 & 13 of 22 & 21 of 22 & 8 of 22 \\
\hline 22 & Problems in quality management arise. & 22 & 2 of 22 & 8 of 22 & 9 of 22 & 4 of 22 \\
\hline 23 & Problems arise due to strikes at headquarters. & 22 & 8 of 22 & 15 of 22 & 15 of 22 & 10 of 22 \\
\hline 24 & Problems arise due to strikes at subcontractors. & 22 & 5 of 22 & 15 of 22 & 15 of 22 & 10 of 22 \\
\hline 25 & Time schedule is exceeded and does not go according to plan. & 22 & 3 of 22 & 3 of 22 & 3 of 22 & 17 of 22 \\
\hline 26 & Budget is exceeded and does not go according to plan. & 22 & 2 of 22 & 7 of 22 & 12 of 22 & 18 of 22 \\
\hline 27 & Discontinuity of incentive programs by local government & 22 & 22 of 22 & 10 of 22 & 10 of 22 & 10 of 22 \\
\hline 28 & Decline in demand for new vessels & 22 & 22 of 22 & 16 of 22 & 16 of 22 & 16 of 22 \\
\hline 29 & Bankruptcy of local suppliers & 22 & 22 of 22 & 14 of 22 & 10 of 22 & 4 of 22 \\
\hline 30 & Delays in construction due to lack of licenses required. & 22 & 22 of 22 & 4 of 22 & 2 of 22 & 2 of 22 \\
\hline
\end{tabular}

The results revealed that Table 5 were unable to be determine a predominant phase of construction for each risk. For example, the respondents appointed risk 12 in $82 \%$ for phase I of construction and also risk 17 had mostly phases II and III corresponding $42 \%$ and $36 \%$ respectively, accounting $78 \%$ for both phases. Moreover, other risks showed a balanced distribution into phases, as for risk 5, which presented phases I, II, III and IV with 23\%, 27\%, 27\%, and $23 \%$ correspondingly. This result shows that risk 5 has all phases of construction related with a minor difference on phases II and III.

As a preliminary finding, one can say that all phases of construction share many risks and it is not possible to identify one phase that is exposed to more 
risks than another. Additionally, some risks in general could not be determined to be exclusive to just one phase of construction.

Next, risks were assessed according to their probability of occurrence and severity of the impact, also as part of Rounds 1 and 2 of this research survey. From the responses received, the outliers were removed based on a MAD (Mean absolute deviation) method. Table 6 shows the average values for both probability and severity obtained, as indicated in columns 5 and 9. Additionally, Columns "Low", "Med" and "High" indicate the quantity of answers assessed for the probability and severity of each risk.

Table 6 - Risk assessment result

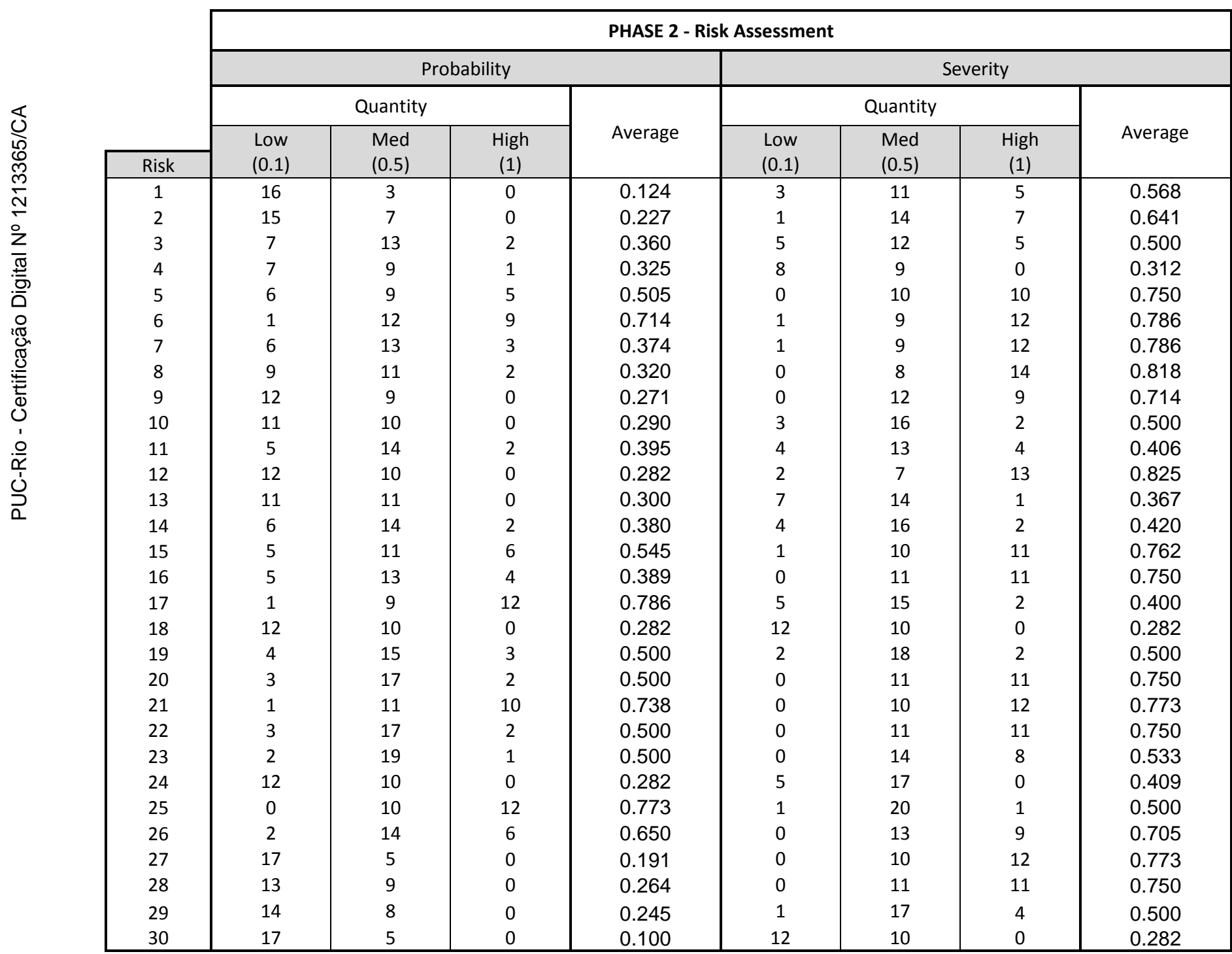


Based on each risk average score of probability and severity, the risks were populated into the risk map/matrix and separated by each risk level group. The result offers an initial risk profile for the shipbuilding industry as presented in Figure14.

Figure 14 - Brazilian shipbuilding risk profile

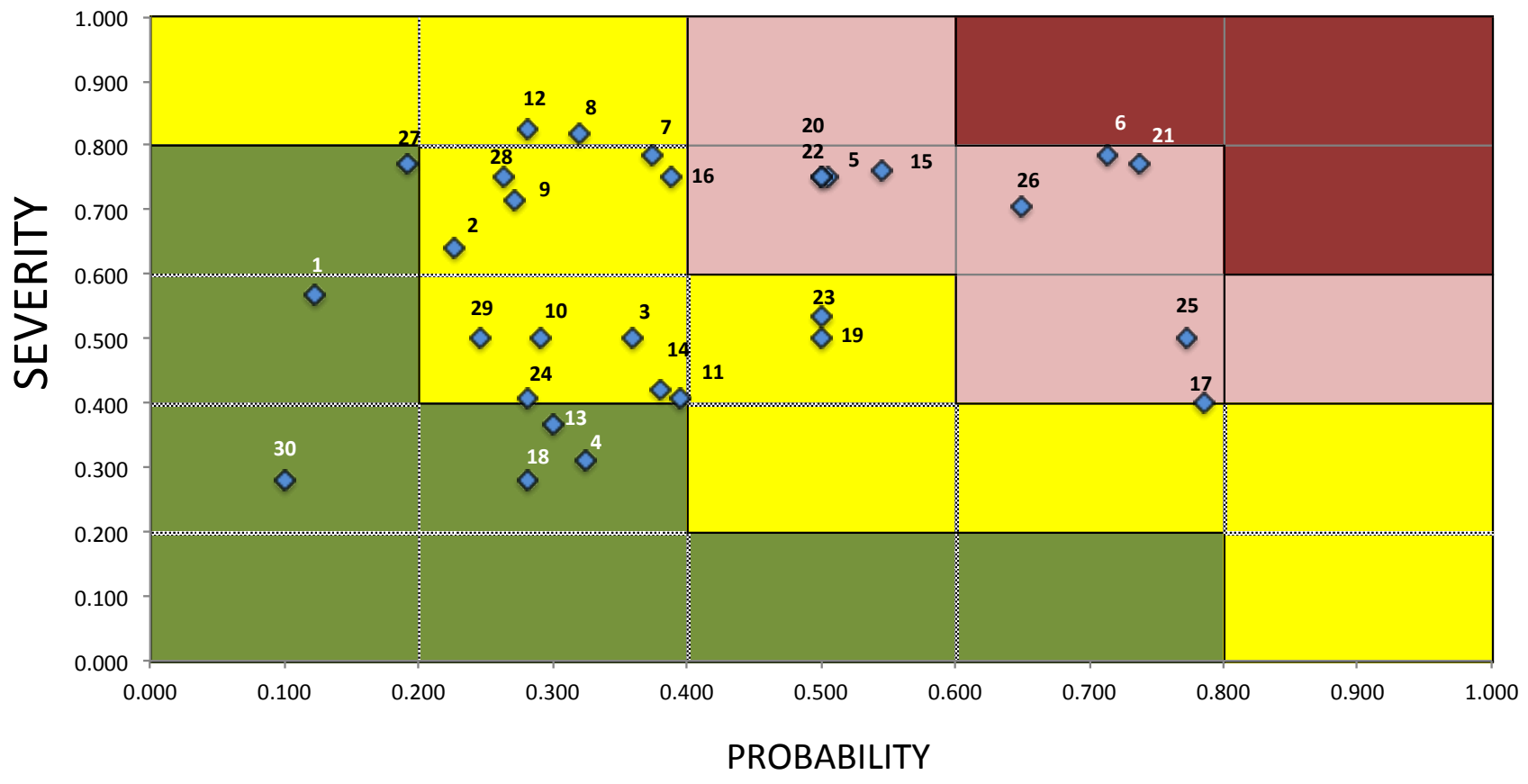

Legend

\begin{tabular}{|c|l|}
\hline RISK LEVEL & \multicolumn{1}{|c|}{ ACTION REQUIRED } \\
\hline VERY HIGH & $\begin{array}{l}\text { Risk mitigation is required.If the risk is not } \\
\text { mitigated monitoring and making a contingency } \\
\text { plan is necessary. }\end{array}$ \\
\hline HIGH & $\begin{array}{l}\text { Risk mitigation is required.If the risk is not } \\
\text { mitigated monitoring and making a contingency } \\
\text { plan is necessary. }\end{array}$ \\
\hline MEDIUM & $\begin{array}{l}\text { Risk mitigation is optional but a monitoring is } \\
\text { required. }\end{array}$ \\
\hline LOW & No further risk mitigation is required \\
\hline
\end{tabular}


The risk profile above demonstrates that the average quantities of risks are presented in the medium risk exposure level group. In this case, a total of 15 risks as medium level, accounting $50 \%$ of the data set, followed by 9 risks classified as High and 6 risks classified as low, as exhibited in Table 7. This outcome indicates that the risks appear to have a clusterization behavior on the medium groups.

Table 7 - Risk exposure levels

\begin{tabular}{ccc} 
Risk numbers & Quantity of risks & Group \\
\hline- & 0 & Very High \\
$6,21,26,17,25,15,5$, & 9 & High \\
20 and 22 & & \\
$23,19,7,16,3,14$, & 15 & Medium \\
$11,8, \begin{array}{l}12,28,9,2,29,10 \\
\text { and } 24\end{array}$ & & Low \\
$27,13,4,18,1$ and & 6 & \\
\hline 0
\end{tabular}

Furthermore, some risks were observed in the same quadrant of risk exposure level. For example, risks numbered 7 and 16 can be difficult to assure which is higher by a risk exposure level. In this case, risk 7 has a higher severity level whereas risk 16 has a higher probability level and they are the same quadrant group.

Shen et al. (2001) shows a good method to distinguish these risks into same quadrant groups, as called Risk Index. Once the risks were ordered, they were also categorized according to their risk source, based on the literature from Table 3, and also remarked as internal or external risk based on Lee et al. (2009). Hence, as shown on Table 8, risks numbered as 21, 6, 26, 25 and 15 are the highest risks for the shipbuilding industry. 
Table 8 - Risk ranking by risk category

\begin{tabular}{|c|c|c|c|c|}
\hline Risk \# & Risk items & Risk Rank & Risk Source & Remark \\
\hline 21 & Productivity does not improve. & 0.514 & Project & Internal \\
\hline 6 & Labor costs rise and cause problems. & 0.509 & Project & Internal \\
\hline 26 & Budget is exceeded and does not go according to plan. & 0.407 & Project & Internal \\
\hline 25 & Time schedule is exceeded and does not go according to plan. & 0.400 & Project & Internal \\
\hline 15 & Unexpected difficulties in cash flow occur. & 0.386 & Project & Internal \\
\hline 16 & There are shortages in design manpower. & 0.370 & Project & Internal \\
\hline 7 & There is difficulty in meeting labor demands for production. & 0.364 & Project & Internal \\
\hline 5 & There is difficulty in supply of raw materials. & 0.363 & Procurement & Internal \\
\hline 20 & Instances arise where the specifications of the shipbuilding contract cannot be met. & 0.355 & Project & Internal \\
\hline 22 & Problems in quality management arise. & 0.343 & Quality & Internal \\
\hline 17 & Changes in design occur. & 0.337 & Project & Internal \\
\hline 23 & Problems arise due to strikes at headquarters. & 0.316 & Disruption & Internal \\
\hline 8 & There is difficulty in supplying production equipment. & 0.298 & Procurement & Internal \\
\hline 11 & Unexpected changes in exchange rates occur. & 0.255 & Procurement & External \\
\hline 19 & Failures in production equipment occur. & 0.243 & Operational & Internal \\
\hline 3 & Classification's rules change and influence shipbuilders. & 0.228 & Sovereign & External \\
\hline 14 & Refund guarantee, operating costs, and other difficulties in capital funding occur. & 0.212 & Project & Internal \\
\hline 12 & Unexpected changes in interest rates occur. & 0.205 & Sovereign & External \\
\hline 28 & Decline in demand for new vessels & 0.202 & Sovereign & External \\
\hline 9 & Unexpected changes in inflation occur. & 0.193 & Sovereign & Internal \\
\hline 27 & Discontinuity of incentive programs by local government & 0.150 & Sovereign & External \\
\hline 29 & Bankruptcy of local suppliers & 0.148 & Disruption & External \\
\hline 2 & Regulations against shipbuilders tighten or are amended & 0.139 & Sovereign & External \\
\hline 10 & New taxes or big changes in tax rates occur. & 0.139 & Sovereign & External \\
\hline 1 & Typhoon, flood, earthquake and other uncontrollable events happen. & 0.124 & Disruption & External \\
\hline 24 & Problems arise due to strikes at subcontractors. & 0.103 & Disruption & Internal \\
\hline 13 & Changes in company credit ratings occur. & 0.096 & Sovereign & External \\
\hline 4 & Incendiary fire or burglaries occur. & 0.086 & Disruption & External \\
\hline 18 & Introduction of new technologies incur new risks. & 0.083 & Project & Internal \\
\hline 30 & Delays in construction due to lack of licenses required. & 0.045 & Sovereign & Internal \\
\hline
\end{tabular}

Based on the Risk map and Table 8, all the risks cited as the highest 5 risks, are all referred to internal risks. According to Alquier and Tignol (2001), internal risks are those that are supposed to be under the company control as production processes. Also as mentioned by Lee et al. (2009), internal risks could be eventually connected or resulted by external risks.

Considering the higher risks 6 (labor cost rise) and 21 (productivity does not improve), from the Round 3 of the survey, the respondents cited that the increase in labor costs in Brazil is primary associated by the ascendant period of the Brazilian shipbuilding industry of investments and ship orders. This current growth has a significant impact on increasing labor-work in the shipyards, as well as the local industry. According to Sinaval (2014), the number of employees rose from nineteen hundred $(1,900)$ in 2000 to seventy eight thousand $(78,000)$ by the end of 2013, as displayed in Figure 15. 
Figure 15 - Brazilian shipbuilding workforce

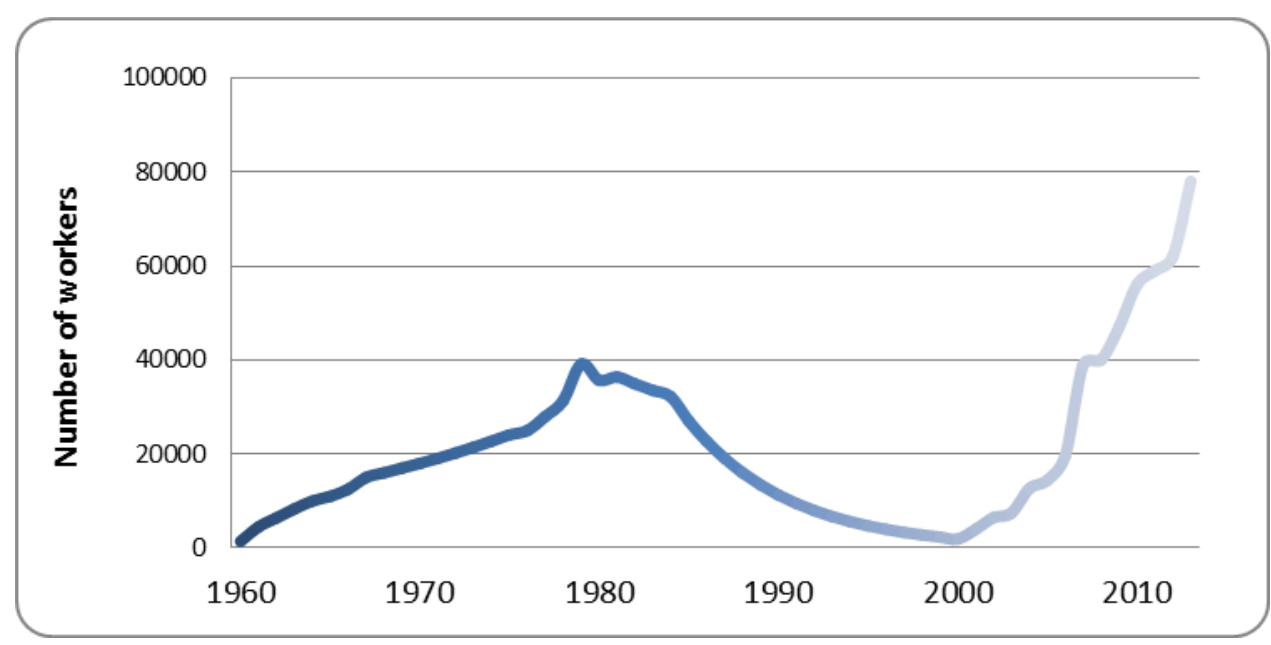

Source: SINAVAL, 2014

Additionally, the respondents consider that the increasing demand on shipbuilding industry creates a highly competitive market for skilled labor, where the number of job offers began to be greater than the number of the experienced professionals available. The cost for skilled labor naturally rises. The outcome shows that local shipyards face a major challenge in training an unqualified workforce in order to make them profitable and productive. The respondents also believe that over the next few years the labor market should stabilize, considering that have been passed almost 15 years since the big recession in the Brazilian shipbuilding industry. Nowadays is more likely to be experiencing a moment of peak. Following this period, a maturation stage should emerge and deflate the base salaries for qualified professionals.

Few shipyards have a mitigation plan for the raise in labor costs of risk number 6 . According to the answers received, some mention that the construction contract signed between shipyards and ship-owners have labor adjustment clauses based on the annual inflation rate or similar, which should be only during the construction timetable period. The common practice is to have a compact number of employees at the shipyard and to subcontract extra workforce according to the production demand. This practice is generally used in large construction projects as for shipbuilding. 
Moreover, using the common measure of man/hours, today Brazilian shipyards spend can spend more than two times man/hours then Asian shipyards. The unqualified workforce not only impacts the productivity for the shipyards, but also increases labor expenditure (Floriano et al., 2010; Goldberg et al., 2010).

Another item that is worth highlighting is that every year in Brazil there is a minimum salary adjustment, based on the annual inflation rate. According to the OECD Economic Outlook 2014, inflation rate project to Brazil in 2015 is around $6 \%$ while Asian countries around 2\%. Besides the Brazilian labor being more expensive to Asian workforce it is also less trained. The outcome is low productivity levels and higher production costs. Consequently, more risk exposure for production delays and exceeding project budget. Moreover, The respondents also mentioned that is not entirely due to unqualified workforce, but also from lack of interest on improvement in production methods and equipment.

Following next higher risk number 26, as for exceeding the budget plan may be a result of the factors as some described above. Based on the responses in Round 3, this can also happen due to a poor budget plan, complexity level of the ship project or higher quality standard required from the ship owners. Many respondents opinion that a poor budget plans is a current reality in the shipyards.

Regarding to exceeding time schedule as risk numbered 25 , the respondents appointed that it can occur for many reasons, including problem with labor (strikes, serious work accident, low productivity), changes in original design, delays in equipment supply, issue for construction license, natural disaster and others.

Results from Lee et al. (2007) and Lee et al. (2009) showed a different behavior between Brazilian and Asian industry, despite the fact that both industries had a similar rapid growth during the last years. According to Clarkson Research (2014), Asian shipyards from 2003 to 2010 increased by almost 260\% for ship orders, while at the same period Brazilian shipyards increased by almost $400 \%$ for ship orders. 
Based on Lee et al. (2007), Korean shipyards have a higher risk for exchange rates and interest rates at delivery phase. Since most of the shipbuilding funding is prepaid by cash and if it is insufficient has to be filled by loans, which is repaid after delivery. The exchange rate and interest rate become significant factors for shipbuilding industry, especially for Asian shipyards, which are characterized as an export industry and every sale is dealt in US Dollars. For the Brazilian shipbuilding, the unexpected change in exchange rates listed as risk number 11, showed to have a lower risk factor. Differently from Lee et al. (2007) result, the Brazilian shipbuilding could be less impacted since mainly supplies the local demand. Besides, according to the respondents, most of local shipyards have foreign investors and in general all income is received in US Dollars while all production costs are dealt in Brazilian Reais, protecting Brazilian shipyards from a possible fluctuations in the rate exchange rate to foreign currencies.

Another items that Brazilian and Asian shipbuilders are not much alike is that Asian shipyards show low risk level for labor strike then the Brazilian shipyards. As already observed in this chapter, Asian shipyards present a higher productivity level as and also with higher use of technology process. Additionally, Asian shipyards have also low level of risk for equipment failure.

Furthermore, Lee et al. (2007) and Lee et al. (2009) showed a critical risk from ship design capabilities and design manpower, while represented with a less risk rate for Brazilian shipyards. According to Faverin et al. (2010 b), the Brazilian shipyards are mainly focused on detailed project design. In some cases, the main project and ship drawings are sourced by foreign engineering offices (Queiroz, 2012; Coutinho, 2006). In contrast, the Asian shipyards have the planning and engineering activities together and also the shipyard designs the entire project (Iskanius and Helaakoski, 2009). This characterizes a much more dynamic department, which also requires a more skilled design labor. This comparison demonstrates why the design manpower shows a less risk in Brazilian shipyards. 


\section{7.}

\section{Conclusion and future research}

This study aimed to fill a gap in the literature regarding the lack of empirical studies for SCRM, focusing on the Brazilian shipbuilding industry. However, it was not intended to exhaust all types of SCRM techniques but rather identify potential risks and develop a risk profile to the Brazilian shipbuilding industry. A survey approach was adopted with 22 respondents, among executives and managers, from 17 significant shipbuilders in Brazil. Together these shipyards cover around $85 \%$ of the total of steel processing capacity in Brazil. The number of the dataset could be considered a study limitation, although it is not believed to compromise the research findings due to the expertise level of the respondents and also because of the representativeness of the shipyards in the Brazilian shipbuilding industry.

As center objective, it was offered an initial risk profile of the Brazilian shipbuilding industry, which presented the risks by their probability and severity of occurrence. The risk profile was constructed through a map/matrix exhibiting four groups of risk exposure. For each group there was a mitigation action associated, found in the literature.

Essentially, the outcome of the survey was that productivity and rise in labor costs are the highest risk factors for Brazilian shipyards. These risks also appeared to have a strong relationship between each other. Comparing to Asian industry, the Brazilian workforce is more expensive and also less trained. The consequence is low productivity levels and higher production costs, which also contribute to a higher risk exposure for production delays and exceeding project budget. Additionally, the main risks obtained were recognized as project risk source, which should be expected in such projectized and complex environment that is shipbuilding. Moreover, the main risks were also observed as an internal environment, indicating that the internal process could be not under control and should be revaluated carefully.

This research appointed to an existing gap regarding to risk mitigation plans and control by local companies. Although the importance of SCRM was 
recognized in the literature, it is possible to observe by other studies conducted in different industries (Ceryno et al., 2014) that the deficiency for a mitigation plan is not exclusive in the shipbuilding industry. Findings from Jüttner (2005), Bloss et al. (2009) and Gunasekaran and Spalanzani (2012) also corroborate that different industries and countries lack in terms of identifying risks and constructing a robust mitigation system. A challenge for SCRM seems to appear in developing ways for risk control and mitigation plans. In this case, a future research turns to be valuable by advancing on Phase II and completing the entire SCRM process. This development would benefit not only the shipbuilding industry but also many others.

Besides, the results also revealed that it was not possible to determine the risks by phase of construction. Unfortunately, the information obtained was not sufficient to affirm, for all cases, if a risk was more presented in a certain stage of construction. Lee et al. (2007) presented a rule association method that allows this examination. However, his approach requires an extensive dataset that might be a challenge for the Brazilian shipbuilding, which could be considered smaller and less experienced, if compared to Asian shipyards. This allows an opportunity for a future research to develop ways to identify risks and investigate by phase of construction. This also can be extended not only to phases but also to any aspect that is desired to be investigated in an industry, such as different manufacturing process, supply chain stages and others. In addition, the relationship of internal and external risks, as well as the type of risk sources could also be explored to better understand the behavior and connection that risks may have.

Furthermore, the findings of this research can be used as a systematic risk management tool for strategic planning. They can be helpful for practitioners to identify and understand risks related to the shipbuilding industry and to recognize their severity and likelihood. This study is particularly relevant to initiate the SCRM, since the risk identification phase is the trigger for this process (Ceryno et al., 2014). Moreover, the adopted methodology can provide guidance in different industries for the SCRM approach.

Noteworthy, this case evidence is only for a single industry, within a single country, which should not be generalized, although some aspects could be 
comparable to other circumstances. All in all, this study took an initial step to investigate the SCRM techniques, offering a significant contribution for empirical research in the literature. 


\section{References}

AITKEN J, CHISTOPHER M and TOWILL, D. Understanding, implementing and exploiting agility and leanness, International Journal of Logistics: Research and Applications 5 (1), 59-74, 2002

AKINTOYE, A. S., and MACLEOD, M. J. Risk analysis and management in construction, International Journal of Project Management, 15(1), 31-38, 1996

ALQUIER, A. M. and TIGNOL, M. H. Project management technique to estimate and manage risk of innovative projects. In IPMA International Symposium and NORDNET 2001, Stockholm, Sweden, 2001

AMARO G, HENDRY $\mathrm{L}$ and KINGSMAN, B. Competitive advantage, customization and a new taxonomy for non-make-to-stock companies, International Journal of Operations \& Production Management 19 (4), 349371,1999

ANSCOMBE, F.J. (1960). Rejection of outliers. Technometrics, 2, 123-147

ARAUJO, F. O. DALCOL P. R. T. and LONGO, W. P. E. A diagnosis of Brazilian shipbuilding industry on the Basis of Methodology for an Analysis of Sectorial Systems of Innovation, Journal of technology management \& innovation, 6 (4), 21, 2011

ARICA, E. and ALFNES, E. A concept for Order Change Management in ETO Supply Chains, Dept of Production and Quality Engineering, Norwegian University of Science and Technology, Abstract 025-1809, 2012

Balance Competitiveness and Benchmarking in the Field of Marine Equipment, Study for the European Commission Directorate-General III D/5 Maritime Industries ETD/98/502029, Bremen, 2000

BASUKI, M., ARTANA, K.B., NUGROHO, S., DINARIYANA, A.A.B. Shipbuilding Industry in Indonesia, a Risk Perspective (in Indonesian), Proceedings of National Seminar of Postgraduate Study 2010, ITS, Surabaya, 2010

BERGER, P.D., GERSTENFELD, A., ZENG, A.Z., How many suppliers are best? A decision-analysis approach, Omega 32 (1), 9-15, 2004

BERTRAND J.W.M. and MUNTSLAG, D.R. Production control in engineerto-order firms, International Journal of Production Economics, 30 (31), 3-22, 1993

BIRMINGHAM, R. MCGREGOR, J. DELAUTRE, S. and ASTRUGUE, J. Risk evaluation at the preliminary design stage of a high-speed craft, journal of ship production, 30 (3), 183-187, 2004 
BLACKHURST, J. CRAIGHEAD, CW. ELKINS, D. HANDFIELD, RB. An empirically derived agenda of critical research issues for managing supplychain disruptions, International Journal of Production Research 43(19), 40674081, 2005

BLOME, C.; SCHOENHERR, T. Supply chain risk management in financial crises - a multiple case study approach. International Journal of Production Economics, 134 (1), 43-57, 2011

BLOS, M.F., Quaddus, M., WEE, H.M. and WATANABE, K., Supply chain risk management (SCRM): a case study on the automotive and electronic industries in Brazil, Supply Chain Management: An International Journal, 14 (4), 247-52, 2009

BOWERSOX, D. J. and CLOSS, D.J. Logistical Management: The Integrated Supply Chain Process. New York: McGraw-Hill Companies, 594, 1996

BURGESS, K. SINGH, J.P. and KOROGLU, R. Supply chain management: a structured literature review and implications for future research, International Journal of Operations \& Production Management, 26 (7), 703-729, 2006

CAMERON, N.S., BRAIDEN, P.M. Using business process re-engineering for development of production efficiency in companies making engineered to order products, International Journal of Production Economics 89 (3), 261-273, 2004

CARON, F. and FIORE, A. Engineer-to-order companies: how to integrate manufacturing and innovative processes, International Journal of Project Management, 13(5), 313-319, 1995

CERYNO, P. SCAVARDA, L.F. KLINGEBIEL, K. Supply Chain Risk:

Empirical Research in the Automotive Industry, Journal of Risk Research, ISSN 1366-9877, 2014

CHAPMAN, C. Project risk analysis and management - PRAM the generic process, International Journal of Project Management, 15(5), 273-281, 1997

CHAPMAN CB, WARD SC. Project risk management: process techniques and insights. 2nd ed. John Wiley and Sons, UK, 2003

CHAPMAN, R.J. Simple Tools and Techniques of Enterprise Risk Management, John Wiley and Sons, p. 494, ISBN 13 978-0-470-01466-0, 2006

CHASE, R.B., et, al. Operations Management for Competitive Advantage. New Delhi: Tata-McGraw-Hill, 11th ed, 2006

CHENG, S.; KAM, H. A conceptual framework for analyzing risk in supply networks. Journal of Enterprise Information Management, 21 (4), 345 - 360, 2008 
CHO, D. S. and PORTER, M. E. Changing global industry leadership: the case of shipbuilding, Massachusetts: Harvard Business School Press, 15-60, 1986

CHOPRA, S. and SODHI, M.S. Managing risk to avoid supply-chain breakdown, MIT Sloan Management Review, 46 (1), 53-62, 2004

CHRISTOPHER, M. and PECK, H. A building the Resilient Supply Chain, International Journal of Logistics Management, 15 (2), 1-14, 2004

CHRISTOPHER, M., LEE, H. Mitigating supply chain risk through improved confidence, International Journal of Physical Distribution and Logistics Management 34 (5), 388-396, 2004

CLARK, D. L., DONNA M. H. and CHARLIE E. W. Improving Shipbuilding Practices Project: Efficiency Through Rework Reduction, Naval Postgraduate School, pg. 1-137, 2007

Clarkson Research Service. Shipping Sector Reports Clarkson Research Service, London, 2014

COUSINEAU, D. and CHARTIER, S. Outliers detection and treatment: A review. International Journal of Psychological Research, 3 (1), 58-67, 2010

COUTINHO, Luciano G., SABBATINI, R. E RUAS, J. A. G. Implantação e consolidação de laboratório de gestão de operações e da cadeia e suprimentos da indústria de construção naval, Programa Tecnológico da Transpetro - Centro de Estudos em Gestão Naval, Escola Politécnica, Universidade de São Paulo. São Paulo, 2006. - Convênio FINEP, 2006

DELOACH, J.W. Enterprise-wide Risk Management. Strategies for Linking Risk and Opportunities, Financial Times/Prentice-Hall, London, 2000

DEY, P. K. Managing project risk using combined analytic hierarchy process and risk map. Applied Soft Computing, 10(4), 990-1000, 2010

DUGUAY, C.R., LANDRY, S. and PASIN, F. From mass production to flexible/agile production, International Journal of Operations \& Production Management, 17 (12), 183-1195, 1997

ELFVING J. Exploration of Opportunities to Reduce Lead Times for Engineered-to-Order Products, Ph.D. Dissertation, University of California, Berkeley, 2003

ELLEUCH, H.; HACHICHA, W.; CHABCHOUB, H. A combined approach for supply chain risk management: description and application to a real hospital pharmaceutical case study. Journal o Risk Research, 15 (5), 641-663, 2014

ENGARDIO, P. Why the supply chain broke down, Business Week, 3724 (19), 41,2001 
EYRES, D. J. Ship Construction, London: Butterworth-Heinemann, Oxford, 2007.

FAVARIN, J., ANDERSON, V. L., AMARANTE, M. R., GALLARDO, P. A., and PINTO, de Oliveira. M. M. Desafios para o ressurgimento da cadeia de fornecedores navais no Brasil, $22^{\circ}$ Congresso Nacional de Transporte Aquaviário, Construção Naval e Offshore, Rio de Janeiro, 2009.

FAVARIN, J. PINTO, de O. M. M., ANDERSON, V. L., BARACAT, M. L. Competitividade da indústria naval brasileira, $23^{\circ}$ Congresso Nacional de Transporte Aquaviário, Construção Naval e Offshore, Rio de Janeiro, 2010 (a)

FAVARIN, J. REQUENA, C. and SOGGIA, L. Desenvolvimento de metodologia de projeto de estaleiro, CEGN, Convênio FUSP-FINEP/CT Aquaviário 01.08.0627.00, 2010 (b)

FINCH, P. Supply chain risk management, Supply Chain Management: An International Journal, 9 (2), 183-96, 2004.

FLANAGAN, R. and NORMAN G. Risk Management and Construction, Cambridge, MA: Royal Institution of Chartered Surveyors, Blackwell Science Ltd, 1993.

FLEISCHER, M. KOHLER R., LAMB, T. BONGIORNI, H. B. and TUPPER, N. Shipbuilding Supply Chain Integration Project, Ann Arbor: Environmental Research Institute of Michigan, 1999.

GALBRAITH, J. R. Designing complex organizations, Addison-Wesley Pub. Co., 1973.

GARDNER, J.T. and COOPER, M.C., Strategic supply chain mapping approaches, Journal of Business Logistics, 24 (2), 37-64, 2003.

GEBHARDT, L. P. and JARVIS, R. G. Productivity improvement at the SENESCO shipyard, Journal of Ship Production, 19 (3), 187-193, 2003

GHADGE, A. DANI, S. CHESTER, M.; KALAWSKY, R. A systems approach for modelling supply chain risks, Supply Chain Management: An International Journal, 18 (5), 523 - 538, 2013.

GILANINIA, S., GANJINIA, H., MAHDIKHANMAHALEH B., A., Difference between internal and external supply chain risk on its performance. Singaporean Journal of business economics, and management studies 8(1), 2013.

GOLDBERG, D. PINTO. DE OLIVEIRA. M. M., CARDOSO, S. J. and FAVARIN, J. Riscos na construção naval brasileira, $23^{\circ}$ Congresso Nacional de Transporte Aquaviário, Construção Naval e Offshore, Rio de Janeiro, 2010. 
GOH M, LIM J. Y. S., MENG F., A stochastic model for risk management in global supply chain networks. European Journal of Operational Research,182(33), 64-173, 2007.

GOSLING, J. and NAIM, M.M. Engineer-to-Order supply chain management: A literature review and research agenda, International Journal Production Economics 122(2), 741-754, 2009.

GOULARTI FILHO, A. Melhoramentos, reaparelhamentos e modernização dos portos brasileiros: A longa e constante espera, Economia e Sociedade, 16 (3),31, 2007.

FLORIANO C. M. P. Jr., LORENA F., G., LUIZ F. A., Marcela F. A. Marcos B C. N., Mauro Rezende F., Nelson D. F., Rogerio M., C., Silvia C. B. Um sistema integrado para acompanhamento e controle de projetos de construção naval, $23^{\circ}$ Congresso Nacional de Transporte Aquaviário, Construção Naval e Offshore, 2010 .

GUNASEKARAN, A. Design and implementation of agile manufacturing systems, International Journal of Production Economics, 62 (3), 1-6, 1999.

GUNASEKARAN, A. and Spalanzani, A. Sustainable supply management: An empirical study, International Journal of Production Economics, 140(1), 168182,2012

HALLIKAS, J. VIROLAINEN, V.M. and TUOMINEN, M. "Risk analysis and assessment in network environment - a dyadic case study", Preprints of the 11th International Working Seminar on Production Economics, 255-70, 2000

HALLIKAS, J.; VIROLAINEN, V.; TUOMINEN, M. Risk analysis and assessment in network environments: A dyadic case study. International Journal of Production Economics, 78 (1), 45-55, 2002

HALLIKAS, J.; KARVONEN, I.; PULKKINEN, U.; VIROLAINEN, V. M.; TUOMINEN, M. Risk management processes in supplier networks. International Journal of Production Economics, 90 (1), 47-58, 2004

HAMERI, A. P. Project management in a long-term and global one-of-akindproject, International Journal of Project Management, 15 (3), 151-157, 1997

HAMPEL, F. R. The influence curve and its role in robust estimation. Journal of the American Statistical Association, 69 (346), 383-393, 1974

HARLAND, C. Risk in supply networks Journal of Purchasing and Supply Management, 9 (2), 51-62, 2003

HARLAND, C., Brenchley, R. and WALKER, H. Risk in supply networks, Journal of Purchasing and Supply Management, 9 (2), 51-62, 2003 
HENDRICKS, K.B. and SINGHAL, V.R. An empirical analysis of the effect of supply chain disruptions on long-run stock price performance and equity risk of the firm, Production and Operations Management, 14 (1), 35-52, 2005

HICKS, C., McGOVERN, T. and EARL, C.F. Supply chain management: A strategic issue in engineer to order manufacturing, International Journal Production Economics 65 (1), 179-190, 2000

HICKS, C., MCGOVERN, T. and EARL, C.F. A Typology of UK Engineer-toOrder Companies, International Journal of Logistics: Research and Applications, 4 (1), 2001

HOESKSTRA, S. and ROMME, J. Integral Logistics Structures: Developing Customer Oriented Goods Flow, IACCOCA, McGraw-Hill, London, 1992

HOWELL, D. C. Statistical methods in human sciences. New York: Wadsworth, 1998

ISKANIUS, P. and HELAAKOSKI, H. Agility in a project-oriented supply chain, International Journal of Management and Enterprise Development. 7 (4), 358-372, 2009

JAIN, J. Dangayach, G. S. AGARWAL, G. and BANERJEE, S. Supply Chain Management: Literature Review and Some Issues. Journal of Studies on Manufacturing, 1 (1), 11-25, 2010

JÜTTNER, U., Peck, H. and CHRISTOPHER, M. Supply Chain Risk Management: outlining an agenda for future research, International Journal of Logistics Management: Research and Application 6 (4), 197-210, 2003

JÜTTNER, U. Supply Chain Risk Management, International Journal of Logistics Management 16 (1), 120-141, 2005

KANERVA, M. Modern-competitive ship construction, Relatório Técnico SOBENA, Rio de Janeiro, 2004.

KARIM, M.A., SMITH, A.J.R. and HALGAMUGE, S., Empirical relationships between some manufacturing practices and performance, International Journal of Production Research, 46 (13), 358-613, 2008

KARJALAINEN, J. HAAHTELA, T. MALINEN, P. and SALMINEN, V. Risk sharing in partnerships embracing new product development. One view, one world of OM? , paper presented at Euroma - POMS Conference, Lake Como, Italy, July 16-18, 2003

KERN, D., MOSER, R. HARTMANN, E. MODER, M. Supply risk management: model development and empirical analysis, International Journal of Physical Distribution \& Logistics Management, 42 (1), 60 - 82, 2012. 
KHAN, O. and BURNES, B. Risk and supply chain management: creating a research agenda, The International Journal of Logistics Management, 18 (2), 197-216, 2007

KLEINDORFER, P.R., SAAD, G.H. Managing disruption risks in supply chains, Production and Operations Management 14 (1), 53-68, 2005

KNIGHT, Frank H. Risk, Uncertainty, and Profit, Hart, Schaffner, and Marx Prize Essays, no. 31. Boston and New York: Houghton Mifflin, 1921

KOENIG, P. C. Structure and Performance in Heavy Industry: The Case of Shipbuilding, George Washington University, May, 1999.

KRALJIC, P. Purchasing must become supply management, Harvard Business Review, 61(5), 109-17, 1983

LAMB, T. Design/production integration, Ch.14 Ship Design and Construction, (Ed. T.Lamb), SNAME, pp.14.1-14.70, 2003

LAMBERT, D.M. and COOPER, M.C. Issues in supply chain management, Industrial Marketing Management, 29(1), 65-83, 2000

LAMPEL, J., MINTZBERG, H. Customizing customization, Sloan Management Review 38 (1), 21-30, 1996.

LEE, E. SHIN, J.G. and PARK, Y. A Statistical Analysis of Engineering Project Risks in the Korean Shipbuilding Industry, Journal of Ship Production, 23 (4), 223-230, 2007.

LEE, E., PARK, Y., and SHIN, J. Large engineering project risk management using a Bayesian belief network, Expert Systems with Applications, 36 (3), 5880-5887, 2009.

LEYS, C. LEY, C. KLEIN, O. BERNARD, P. LICATA. L. Detecting outliers: Do not use standard deviation around the mean, use absolute deviation around the median. Journal of Experimental Social Psychology, 49 (4), 764-766, 2013.

LIKER, J. and LAMB, T. Lean Manufactures Principles Guide, Maritech ASE Project, TIA, 2001.

LIMA, G. P. S. O soerguimento da construção naval brasileira nos anos 2000: uma análise neo-schumpeteriana, Master's thesis, University of Sao Paulo (USP), 2009.

LIU J., ZHAO J, Bullwhip Effect and the Value of Information Sharing in Supply Chain Illustrated by a Shipbuilding Supply Chain, Journal of Harbin Institute of Technology (Social Science Edition), 3(5), 29-34, 2006. 
LU, B. Z., and TANG, A. S. T. China shipbuilding management challenges in the 1980s, Maritime Policy \& Management, 27(1), 71-78, 2000.

LUMMUS, R. VOKURKA, R. Defining supply chain management: a historical perspective and practical guidelines, Industrial Management \& Data Systems, 99 (1), 11-17, 1999.

LUSTOSA, L., MESQUITA, M.A. Quelhas and O. Oliveira, R. Planejamento e controle da Produção, Editora Elsevier, Rio de Janeiro, 2008

MACINTOSH, G., Perceived risk and outcome differences in multi-level service relationships, Journal of Services Marketing, 16 (2), 143-57, 2002.

MANUJ, I. and MENTZER, J.T. Global supply chain risk management, Journal of Business Logistics, 29 (1), 133-55, 2008.

MARTHA, J. and SUBBAKRISHNA, S. Targeting a just-in-case supply chain for the inevitable next disaster, Supply Chain Management Review, 6 (5), 1823, 2002.

MASON-JONES, R. and TOWILL, D.R. Information enrichment: Designing the supply chain for competitive advantage, Supply Chain Management 2 (4), 137-148, 1997.

MCCLELLAND, G. H. Nasty data: Unruly, ill-mannered observations can ruin your analysis. In H. T. Reis, \& C. M. Judd (Eds.), Handbook of research methods in social and personality psychology (pp. 393-411). Cambridge: Cambridge University Press, 2000.

MCDERMOTT, R.E., MIKULAK, R.J. and BEAUREGARD, M.R., The Basics of FMEA, Productivity Inc, Portland, OR, 1996.

MCGILLIVRAY, G. Commercial risk under JIT, Canadian Underwriter, 67 (1), 26-30, 2000.

MENTZER, J.T., DEWITT, W., KEEBLER, J.S., MIN, S., and Al, E. Defining supply chain management, Journal of Business Logistics, 22 (2), 1-25, 2001.

MILLER, J. Reaction time analysis with outlier exclusion: Bias varies with sample size. The Quarterly Journal of Experimental Psychology, 43 (4), 907-912, 1991.

MOHAN, M., S. Sodhi1, Byung-Gak Son1 and Christopher S. Tang Researchers Perspectives on Supply Chain Risk Management, Production and Operations Management 21 (1), 1-13, 2012.

MOJTAHEDI, S.M. H. MOUSAVI, S.M., and AMINIAN, A. Fuzzy group decision making: A case using FTOPSIS in mega project risk identification and analysis concurrently. International Conference on Industrial Engineering and Engineering Management, 1 (3), 1769-1773, 2008. 
MONTES, A. Plant Layout of a Shipyard, Ship Production and Ship Procurement WEMT, 1993.

MOURA, D. A. Análise dos principais segmentos da indústria marítima brasileira: estudo das dimensões e fatores críticos de sucesso inerentes à sua competitividade, Tese de Doutorado Escola Politécnica, Departamento de Engenharia Naval e Oceânica, Universidade de São Paulo, 2008.

MOYST, H., and DAS, B. Factors affecting ship design and construction lead time and cost, Journal of Ship Production, 21(3), 186-194, 2005

NAIM, M. NAYLOR, J. BARLOW, J. Developing lean and agile supply chains in the UK housebuilding industry, Proceedings of the Seventh Annual Conference of the International Group for Lean Construction IGLC-7, Berkeley, 26(28), 159-170, 1999

NAYLOR, B. NAIM, M.M. and BERRY, D. Leagility: Integrating the lean and agile manufacturing paradigmsin the total supply chain, Int. J. of Prod. Econ 62 (4), 107-118, 1999.

NEW, S.J., PAYNE, P. Research frameworks in logistics: three models, seven dinners and a survey, International Journal of Physical Distribution and Logistics Management 25 (10), 60-77, 1995.

NG, M.F., TUMMALA, V.M.R. and YAM, C.Y., A risk based maintenance management model for toll road/tunnel operations, Construction Management and Economics, 21(5), 495-510, 2003.

NIEGER, D. ROTARU, K. and CHURILOV, L. Supply chain risk identification with value-focused process engineering, Journal of Operations Management, 27(2), 154-168, 2009.

NORRMAN, A. and JANSSON, U. Ericsson's proactive supply chain risk management approach after a serious sub-supplier accident. International Journal of Physical Distribution \& Logistics Management, 34(5), 434-56, 2004.

OSBORNE, J. W. and OVERBAY A. The power of outliers (and why researchers should always check for them). Practical Assessment, Research and Evaluation, 9(6), 2004.

OEHMEN, J., ZIEGENBEIN, A., ALARD, R. \& SCHÖNSLEBEN, P. Systemoriented Supply Chain Risk Management. Production Planning and Control, 20, 343-361, 2009.

OLHAGER, J. Strategic positioning of the order penetration point. International Journal of Production Economics, 85(3), 319-329, 2003.

OLHAGER, J. The role of the customer order decoupling point in production and supply chain management, Computers in Industry, 61(9), 863-868, 2010. 
PANDIT, A. and ZHU, Y. An ontology-based approach to support decisionmaking for the design of ETO (Engineer-to-Order) products, Automation in Construction 16 (2), 759-770, 2007.

PARASCHIV, D. and ALBESCU, F. Globalization and developments in shipbuilding industry, 7th International Meeting for Research in Logistics AVIGNON, 24-26, September, 2008.

PILLING, B.K. and ZHANG, L. Cooperative exchange: rewards and risks, International Journal of Purchasing \& Materials Management, 28(2), 2-9, 1992

PIRES JR., F. C. M., ESTEFEN, S. F. and NASSI, C.D. Benchmarking internacional para indicadores de desempenho na construção naval - Rio de Janeiro, COPPE/UFRJ, 2007.

PIRES, S. R. I. Gestão da Cadeia de Suprimentos: conceitos, estratégias, práticas e casos, Editora Atlas, 2004. 310 p., 2004.

PIRES JR, F. LAMB, T., and SOUZA, C. Shipbuilding performance benchmarking, International Journal of Business Performance Management, 11 (3), 2009.

PORTER, K., LITTLE, D., PECK, M., ROLLINS, R. Manufacturing classifications: relationships with production control systems, Integrated Manufacturing Systems 10 (4), 189-199, 1999.

PORTER, M. Competitive Advantage, The Free Press, New York, NY, 1985.

PUJAWAN, I. N. and GERALDIN, L. H. House of risk: a model for proactive supply chain risk management. Business Process Management Journal 15(6), 953-967, 2009.

PUTO, C.P., PATTON, W.E. and KING, R.H., Risk handling strategies in industrial vendor selection decisions, Journal of Marketing, 49, 89-98, 1985.

QUEIROZ, A. A. F. S. L. de. Projeto de Rede de Suprimentos: um modelo colaborativo para estruturação da rede de navipeças na Indústria de Construção Naval do Brasil, Tese (Doutorado) - Escola Politécnica da Universidade de São Paulo, 267 f., 2009.

QUEIROZ, V.J. Análise comparativa de riscos de estaleiros e projetos de construção naval no brasil, Tese de doutorado - Escola Politécnica da Universidade de São Paulo, 2012.

QUINN, F. Risky business. Supply Chain Management Review 10 (4), 5, 2006

RAGATZ, G.L., Handfield, R.B. and Scannell, T.V., Success factors for integrating suppliers into new product development, Journal of Product Innovation Management, 14(1), 190-202, 1997. 
RICE, J.B. and CANIATO, F., Building a Secure and Resilient Supply Network. Supply Chain Management Review, 7(5), 22-30, 2003.

RICHARDSON, R.J. Pesquisa social: métodos e técnicas, São Paulo, Atlas, 1989.

RITCHIE, B. and BRINDLEY, C. Supply chain risk management and performance: a guiding framework for future development, International Journal of Operations and Production Management, 27(3), 303-322, 2007.

ROUSSEEUW, P. J. and CROUX, C. Alternatives to the median absolute deviation. Journal of the American Statistical Association, 88(424), 1273-1283, 1993.

RUDBERG, M. and WIKNER, J. Mass customization in terms of the customer order decoupling point, Production Planning \& Control: The Management of Operations, 15(4),445 - 458, 2004.

ORR, J. M., SACKETT, P. R., and DUBOIS, C. L. Z. (1991). Outlier detection and treatment in I/O Psychology: A survey of researcher beliefs and an empirical illustration. Personnel Psychology, 44, 473-486.

SARDER, MD B. Ali A. FERREIRA, S. and RAHMAN, M.A. Managing Material Flow at the US Shipbuilding Industry, Proceedings of the 2010 International Conference on Industrial Engineering and Operations Management Dhaka, Bangladesh, January 9 - 10, 2010.

SCHANK, J.F. ET AL. Outsourcing and Outfitting Practices: Implications for the Ministry of Defence Shipbuilding Programmes, Santa Monica, California: Rand Europe, Paper prepared for the United Kingdom Ministry of Defense, 2005.

SCHMITT, J. A., SUN, A. S., SNYDER, V. L. SHEN M. Z. M., Centralization versus decentralization: Risk pooling, risk diversification, and supply chain disruptions. Omega article in press, 2014.

SCHOENHERR, T. TUMMALA, V.M.R. HARRISON, T.P. Assessing supply chain risks with the analytic hierarchy process: providing decision support for the offshoring decision by a US manufacturing company. Journal of Purchasing \& Supply Management, 14, pp. 100-111, 2008.

SCOTT, C., WESTBROOK, R. New strategic tools for supply chain management. International Journal of Physical Distribution and Logistics 21 (1), 23-33, 1991.

SHARMA, K. Logistic Management: A Competitive Advantage for the New Millennium. Global India Publications Ltd, First edition, 2009.

SHARMAN, G. The rediscovery of logistics, Harvard Business Review, 62(5), 71-80, 1984. 
SHEN LY, WU G.W.C. NG C.S.K. Risk assessment for construction joint ventures in China, J Constr Eng Manage 2001.

SIMCHI-LEVI, D. KAMINSKY, P. SIMCHI-LEVI, E. Designing and Managing The Supply Chain: Concepts, Strategies and Case Studies, 3rd Edition. McGraw-Hill Irwin, 2008.

SINAVAL, Cenário 2014. Sindicato Nacional da Indústria da Construção e Reparação Naval e Offshore, 2014.

SLACK, N., CHAMBERS, S. and JOHNSTON, R. Operations management, Financial Times, Prentice Hall 6th edition, 2009.

SODHI, M. SON, B. and TANG, C. Researchers' Perspectives on Supply Chain Risk Management, Production and Operations Management, 21(1), 1-13, 2012.

STOPFORD, M. World Sea Trade Outlook; Where China fits into the global picture, Exploring Shipping Business in China Mareforum and Tradewinds Shangai Conference, 2005.

SUN X. Y, JI P., SUN L.Y. and WANG Y.L. Positioning multiple decoupling points in a supply network, International Journal of Production Economics, 113 (2), 943-956, 2008.

TANCREDI, P. T., JUNIOR, A. C. P., Issisaki, A.C., Filho, L. R. E. J. Projeto de um estaleiro para construção em larga escala de navios de apoio marítimo, $24^{\circ}$ Congresso Nacional de Transporte Aquaviário, Construção Naval e Offshore, Rio de Janeiro, 2010.

TANG, C.S. Robust strategies for mitigating supply chain disruptions. International Journal of Logistics 9 (1), 33-45, 2006.

TANG, O. and MUSA, N S. Identifying risk issues and research advancements in supply chain risk management, International Journal of Production Economics 133 (1), 25-34, 2011.

TAZELAAR, F., SNIJDERS, C. Operational risk assessments by supply chain professionals: Process and performance, Journal of Operations Management 31 (4), 37-51, 2013.

THUN, JH. and HOENIG, D. An empirical analysis of supply chain risk management in the German automotive industry, International Journal of Production Economics 131 (1), 242-249, 2009.

TUMMALA, V.M.R., NKASU, M.M. and CHUAH, K.B., A framework for project risk management, ME Research Bulletin, 2 (1), 145-71, 1994. 
TUMMALA, R. and SCHOENHERR, T. Assessing and managing risks using the Supply Chain Risk Management Process (SCRMP), Supply Chain Management: An International Journal, 16 (6), 474-483, 2011.

TUMMALA, V.M.R. and MAK, C.L., A risk management model for improving operation and maintenance activities in electricity transmission networks, Journal of the Operational Research Society, 52 (2), 125-34, 2001.

TUNCEL, G.; ALPAN, G. Risk assessment and management for supply chain networks: A case study. Computers in Industry, 61 (3), 250-259, 2010.

VAN DONK, D.P. Make to stock or make to order: the decoupling point in the food processing industries, International Journal Production Economics, 69 (3), 297-306, 2001.

VAN HOEK, R. I., Peelen, E. and COMANDEUR, H. R. Achieving mass customization through postponement: a study of international changes, Journal of Market Focused Management, 3 (2), 353-368, 1999.

WAGNER, S. M. BODE C. An empirical investigation into supply chain vulnerability, Journal of Purchasing and Supply Management, 12 (6), 301- 12, 2006.

WALTER, C and RIES, O. A Automação da Engenharia de Produto em um Ambiente ETO/OKP, Máquinas e Metais, 132-139, 1996.

WARD, S. Requirements for an effective project risk management process, Project Management Journal 30 (3), 37-43, 1999.

WANG JY, Liu CL. Risk management for construction projects, Construction Management and Economics, 22(3), 2004.

YANG, B., BURNS, N.D. and BACKHOUSE, C.J. Postponement: a review and an integrated framework. International Journal of Operations \& Production Management 24 (5), 468-487, 2004.

YATES, J.F., STONE, E.R., Yates, J.F. (Ed.), The Risk Construct in RiskTaking Behavior. Wiley, Chichester, 1-25

ZOU, P. X. W. ZHANG, G. WANG, J. Understanding the key risks in construction projects in China. International Journal of Project Management, 25 (6), 601-614, 2007.

ZSIDISIN, G.A. and ELLRAM, L.M. An agency theory investigation of supply risk management, The Journal of Supply Chain Management, 39 (3), 15-27, 2003. 


\section{Appendix I - Survey Rounds 1 and 2}

Dear (a) participant,

This present questionnaire is one of the data collection instruments for conducting the master's dissertation research in logistics, developed by the student Felipe Ferreira of Production Engineering Department of PUC-Rio and advised by Prof. Luiz Felipe Scavarda and Adriana Piles, and

Your participation is of fundamental importance to assist statistics development and verification of the proposed questions for the shipbuilding Industry study in Supply Chain Risk Management. In this way, we would ask the kindness to individually fill out these forms.

We appreciate your attention and we are at your disposal for any questions or clarifications.

Kind Regards,

Felipe Azevedo Lage Ferreia,

Master in Logistics

Pontifical Catholic University of Rio de Janeiro

msc.felipeferreira@gmail.com 


\section{First Round}

The first round of the questionnaire has two (2) parts:

\section{Part I:}

The first part has 30 rows and seven (7) columns. The first column presents the main risks associated to shipbuilding featured in the academic literature. The second column associates these risks with the probability of their occurrence and the third to the size of its impact (severity of the consequences if they occur). The four columns (4) to seven (7) present the four main phases of construction of this industry. Please complete this part of the questionnaire in the following steps:

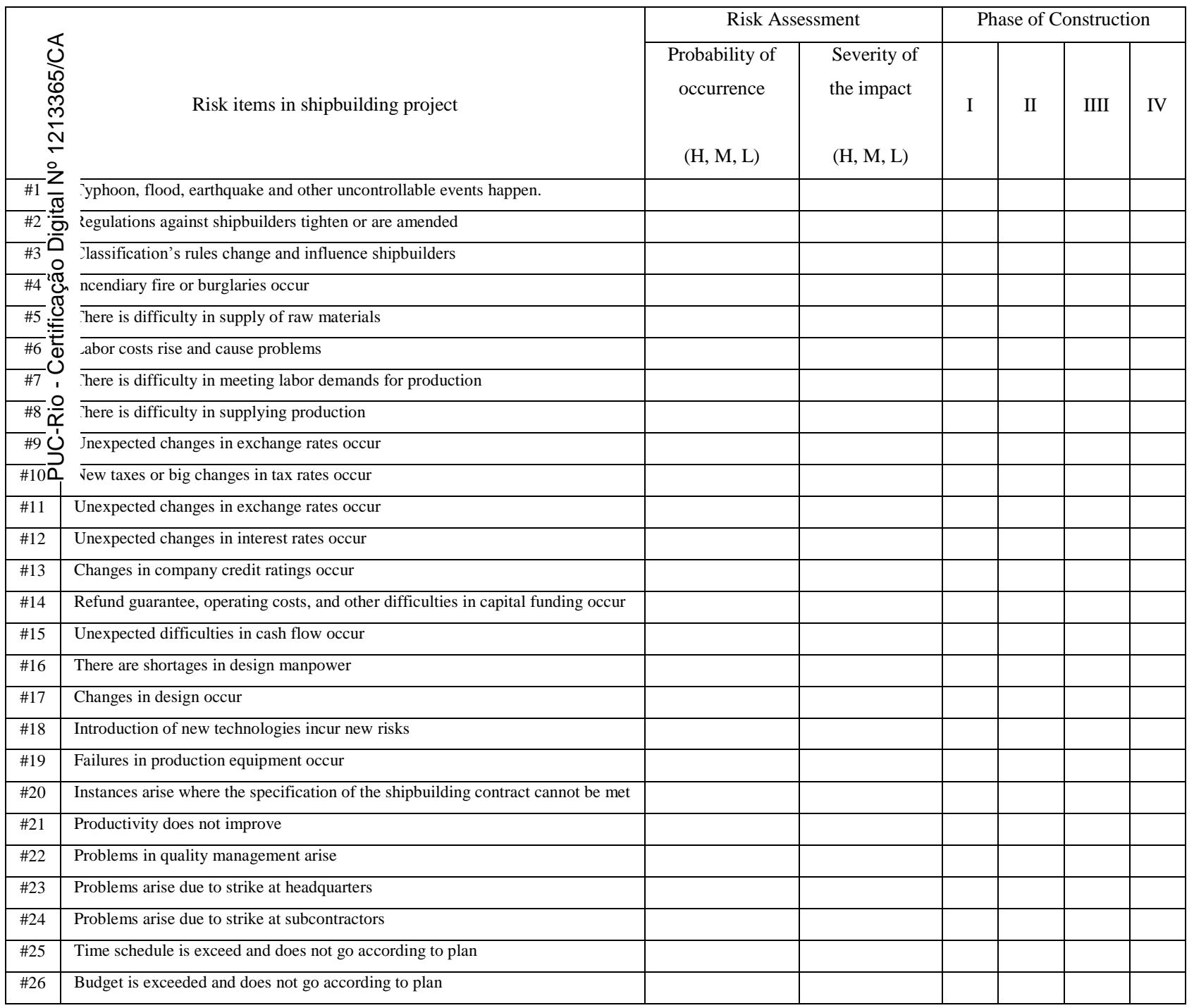


Step 1)

a. Please validate if each listed risk below is presented in the Brazilian Shipbuilding industry. Please do not fill the columns 2-7 for the risks it deems not relevant to the Brazilian reality.

b. Please fill in column 2 associating the risk with their probability of occurrence (low, medium, high)

c. Please fill in column 3 associating the risk to the size of its impact in case of occurrence (low, medium, high)

d. Please fill in columns 4 to 7 the construction phase in which the risk is present, which may be present in only one stage or more of the following phases:

PHASE I - Contract / Steel processing (Column 4)

PHASE II - Keel Laying / Block assembly (Column 5)

PHASE III - Hull launching / Outfitting (Column 6)

PHASE IV - Commissioning / Delivery (column 7)

Step 2)

In your opinion, if any additional risks to the 26 listed in the first column, the questionnaire offers in lines 27-30 the possibility of adding up to four new risks (additional risk I, II additional risk, additional risk III, IV additional risk). 
Please fill in the remaining columns for each additional risk as the previous procedure and in the "other" specify the name of each.

\section{Second Round}

Based on the result from Round 1, four new risks were identified to be present in the Brazilian shipbuilding Industry, as follows:

27. Discontinuity of incentive programs by local government

28. Decline in demand for new vessels

29. Bankruptcy of local suppliers

30. Delays in construction due to lack of licenses required.

In this case, please repeat sub steps "b","c" and "d" from step 1 for the four new risks listed above. 


\section{Appendix II - Survey Round 3}

\section{Third Round}

From the previous Rounds the survey, the results demonstrated that 5 from 30 listed risks were identified as high risk of exposure, considering their probability of occurrence and severity of the impact. The 5 risks are:

- Rise in labor costs

- Changes in design

- Productivity rates does not improve

- Time schedule is exceeded

- Budget is exceeded

Based on the listed 5 risks, please answer the following questions for each type of risk:

1) What are the main causes for the said risks to occur?

2) What can be done to avoid the listed risks? Is there any mitigation strategy?

3) Please give examples if the said risks have happened to the shipyard you work for, and if yes, how was the impact for this risk and what were the main consequences? 